\title{
A New Era of Targeting the Ancient Gatekeepers of the Immune System: Toll-Like Agonists in the Treatment of Allergic Rhinitis and Asthma
}

\author{
Zahra Aryan $^{a}$ Stephen T. Holgate ${ }^{c}$ Danuta Radzioch ${ }^{e}$ Nima Rezaej $^{a, b}$, d \\ ${ }^{a}$ Molecular Immunology Research Center and Department of Immunology, School of Medicine and ${ }^{\mathrm{b}}$ Research \\ Center for Immunodeficiencies, Pediatrics Center of Excellence, Children's Medical Center, Tehran University of \\ Medical Sciences, Tehran, Iran; ${ }^{C}$ Faculty of Medicine, Clinical and Experimental Sciences, Southampton General \\ Hospital, Southampton, and ${ }^{\mathrm{d} D e p a r t m e n t}$ of Infection and Immunity, School of Medicine and Biomedical Sciences, \\ University of Sheffield, Sheffield, UK; ${ }^{e}$ Department of Medicine and Department of Human Genetics, McGill \\ University, Montreal, Que., Canada
}

\section{Key Words}

Toll-like receptors . CD14 · Hygiene hypothesis . Innate immunity - Immunotherapy · Adjuvants . CpG oligodeoxynucleotide $\cdot$ Immunostimulatory sequence oligonucleotides . Asthma . Allergic rhinitis

\footnotetext{
Abstract

Toll-like receptors (TLR) belong to a large family of pattern recognition receptors known as the ancient 'gatekeepers' of the immune system. TLRs are located at the first line of defense against invading pathogens as well as aeroallergens, making them interesting targets to modulate the natural history of respiratory allergy. Agonists of TLRs have been widely employed in therapeutic or prophylactic preparations useful for asthma/allergic rhinitis (AR) patients. MPL ${ }^{\circledR}$ (a TLR4 agonist) and the CpG oligodeoxynucleotide of 1018 ISS, a TLR9 agonist, show strong immunogenicity effects that make them appropriate adjuvants for allergy vaccines. Targeting the TLRs can enhance the efficacy of specific allergen immunotherapy, currently the only available 'curative' treatment for respiratory allergies. In addition, intranasal administration of AZD8848 (a TLR7 agonist) and VTX-1463 (a TLR8
}

agonist) as stand-alone therapeutics have revealed efficacy in the relief of the symptoms of AR patients. No anaphylaxis has been so far reported with such compounds targeting TLRs, with the most common adverse effects being transient and local irritation (e.g. redness, swelling and pruritus). Many other compounds that target TLRs have been found to suppress airway inflammation, eosinophilia and airway hyperresponsiveness in various animal models of allergic inflammation. Indeed, in the future a wide variability of TLR agonists and even antagonists that exhibit anti-asthma/AR effects are likely to emerge.

(c) 2014 S. Karger AG, Basel

\section{Introduction}

Atopic asthma and allergic rhinitis (AR) represent two closely related allergic diseases of the respiratory system [1]. The prevalence of these two diseases has increased over the past decades and, with respect to the costs, side effects and failures of conventional long-term symptomatic treatments or low compliance with allergen avoidance, many efforts have been made to find novel thera-

\section{KARGER}

E-Mail karger@karger.com

www.karger.com/iaa (c) 2014 S. Karger AG Basel

1018-2438/14/1641-0046\$39.50/0
Correspondence to: Dr. Nima Rezaei

Children's Medical Center Hospital

Dr. Qarib Street, Keshavarz Boulevard

Tehran 14194 (Iran)

E-Mail rezaei_nima@tums.ac.ir 
peutics [2]. So far, specific allergen immunotherapy (SIT) represents the only 'etiologic' treatment that directs towards the basis of atopic respiratory disease and influences the natural history of AR and asthma [3]. To develop safer and more efficacious allergy vaccines or novel stand-alone therapeutics, innate immunity stands out as a major target since it is the first line of defense $[4,5]$. Innate immunity enables initial recognition of invading pathogens and presents them to the immune system to elicit an appropriate adaptive immune response. Pattern recognition receptors (PRRs) represent ancient and conserved structures of the innate immune system with endosomal, cell-membrane bound and soluble members that discriminate self from non-self [6]. They recognize patterns that are common among invading pathogens and orchestrate subsequent immune responses [7]. Tolllike receptors (TLR), C-type lectin receptors, nucleotidebinding oligomerization domain-like receptors and retinoic acid-inducible gene-1-like receptors are all members of the growing family of PRRs expressed in airway cells $[8,9]$.

TLRs exert dual roles in allergic diseases; activation of some TLRs offer sensitizations and breaking of the tolerance [10-12], while activation of some members of this family, particularly early in life, may promote tolerance to innocuous aeroallergens. The hygiene hypothesis suggests that a reduced microbial burden in early childhood increases the susceptibility to allergic disease via deficient maturation of the immune system [13]. Recently, the PASTURE study (Protection against Allergy: Study in Rural Environments) has shown that early-life exposure to a livestock farming environment, as well as drinking raw milk in the first year of life, reduces the chance of the allergic phenotype emerging by an overall increase in PRR gene expression [14]. On the other hand, Holt et al. [3] introduced the 2-Hit model of asthma in which atopy together with viral respiratory infections such as rhinovirus, respiratory syncytial viruses (RSV) and other respiratory viruses synergistically increase the risk of asthma in the presence of allergen exposure $[3,15,16]$. This shows that not all infections and not all farming environments are protective. Interestingly, many triggers of asthma, such as environmental allergens and air pollutants, act in part via modulation in PRR expression and function [1720]. Furthermore, the generation of reactive oxygen species is increased in asthma and AR, with oxidative stress being one factor that causes exacerbation of disease. Interestingly, transcriptional factors activated through TLR signaling (e.g. NF- $\mathrm{kB}$ ) are redox sensitive and several anti-oxidant agents have been demonstrated to inhibit asth- ma symptoms by reduction of reactive oxygen species generation [21-24]. In addition, the consumption of probiotics, which has been proposed to prevent allergic diseases, might work via modulation of TLRs [25-27].

TLRs are pivotal actors in shaping the effective and healthy adaptive immunity with the development of immune deviation from the T-helper (Th) 2 to Th1 phenotype and maturation of T-reg cells [28, 29]. Interestingly, the expression and function of TLRs [30-34] were demonstrated to be different in patients with asthma/AR as compared to healthy subjects. This difference in immune defense may be one of the possible reasons for the increased susceptibility to respiratory infections displayed by these patients. On the other hand, it has also been shown that impaired function of TLRs may be reversible through appropriate immunotherapy [35] or other medications used frequently for patients with allergy [36]. This observation offers real promise for immunotherapeutic approaches to restore the protective immune response in the airways of allergic subjects [37]. In this review, we summarize the results of studies on in vivo specific targeting of TLRs using animal models of allergic asthma, clinical trials I-IV and registries of clinical trials focused on specific targeting of TLRs in humans. The highest level of evidence provided by each study has been determined according to Oxford Centre for EvidenceBased Medicine (OCEBM) 2011, and thereby the highest level of evidence for efficacy of each compound has been extracted (Box 1). The results are categorized under appropriate subheadings. Overall, our review strongly suggests that TLR targeting may arrest the disease progression of an allergic response either by induction of tolerance to allergens (e.g. SIT) and/or by redirecting the immune response away from the airways.

\section{Cell Surface TLRs}

Cell surface TLRs have an active role in the identification of structural components at the cell surface of invading pathogens. Wide varieties of gram-positive and negative bacteria, as well as some viruses such as RSV [38, 39], known as risk factors for triggering the allergic airway disease, are recognized by these TLRs. To expand signaling, Toll/interleukin (IL)-1 receptor (TIR) domain-containing adaptors are employed and, with the mediation of TIR domain-containing adaptor protein (TIRAP) and myeloid differentiation primary response gene 88 (MyD88), a cascade is triggered that finally leads to the translocation of interferon regulatory factors $3 / 7$, AP1 
To find relevant articles the databases of MEDLINE, Scopus and EMBASE were searched with keywords of 'TLR1-10', 'airway', 'asthma', 'allergy', 'rhinitis', 'CpG', 'AIC', 'QbG10', 'AZD1419', 'AEV0675', 'SAR21609', 'IMO2134', 'VTX-1463', 'R848', 'R837', 'AZD8848', 'polyI:C', 'Resveratrol', 'ssDNA-ODN', 'Capsazepinoids', 'MALP-2', 'Pam3Cys', 'Pam3CSK4', 'Zymosan', 'Opr 1', 'LP40', 'MPL', 'PGA', 'CRX-675', 'E5564' and 'flagellin'. Furthermore, hand searching was performed by checking all reference lists of articles provided by the electronic search. No time limitation or language restriction was used and whenever the required data of publication was inaccessible, we contacted the corresponding author to provide it. It is of note to say that no preference was given to include studies and all in vivo studies that employed PRR agonists or antagonists in airway hyperresponsiveness, whether on animal models or human subjects, were included in this review. Duplicated studies provided by searching the databases of MEDLINE, Scopus and EMBASE were excluded and preference was given to more recent and comprehensive in vitro studies. The highest level of evidence found in all possible sources from experimental studies to phase I-IV clinical trials in human subjects has been diligently summarized in this review. In accordance with 'OCEBM 2011 Levels of Evidence' and study design, the level of evidence provided by each study has been determined. According to OCEBM-2011, mechanism-based reasoning studies provide level 1, case series, case-control studies, or historically controlled studies provide level 2, non-randomized cohort studies provide level 3 , randomized trials provide level 2 and systematic review and metaanalysis of randomized trials provide level 1 of evidence.
On the other hand, since a large amount of data relating to this topic may be unpublished and therefore not indexed in searched databases, we also searched the International Clinical Trials Registry Platform (ICTRP) of the World Health Organization (WHO) with the same keywords to find registries that used agonists or antagonists of PRRs in human subjects with airway hyper-responsiveness (last update of December 2012). ICTRP provides a monthly update of registries from the following registry systems: (1) Australian New Zealand Clinical Trials Registry (ANZCTR), (2) Chinese Clinical Trial Register (ChiCTR), (3) Clinical Research Information Service (CRiS), Republic of Korea, (4) ClinicalTrials.gov, national library of the USA, (5) Clinical Trials Registry - India (CTRI), (6) Cuban Public Registry of Clinical Trials (RPCEC), (7) EU Clinical Trials Register (EU-CTR), (8) German Clinical Trials Register (DRKS), (9) Iranian Registry of Clinical Trials (IRCT) ISRCTN. org, (10) Japan Primary Registries Network (JPRN), (11) Pan African Clinical Trial Registry (PACTR), (12) Sri Lanka Clinical Trials Registry (SLCTR), and The Netherlands National Trial Register (NTR). Finally, after pooling all eligible studies whether published or unpublished, duplicated results were identified and excluded.

With respect to the heterogeneity of the studies presented in this review in terms of study subjects (animal models or human subjects), variability in reporting of the results for upper or lower respiratory tract and wide spectrum of TLRs, a meta-analysis of various studies has not been performed. Finally, results of eligible studies have been explained in categorized subheadings. and NF- $\kappa B$ to the nucleus [40]. These transcriptional factors enhance type 1 interferon, inflammatory cytokine and chemokine expression, as well as the induction of MUC gene expression (fig. 1) [23, 41-44]. Targeting of these TLRs is based mainly on adjuvants of allergy vaccine, as seen in Pollinex ${ }^{\circledR}$ Quattro [6]. Other therapeutic preparations with agonists or antagonists of cell surface TLRs are also described below.

\section{TLR1, 2, 6 and 10}

TLR2 agonists may act as either allergenic or anti-allergic agents based on the treatment schedule and materials. Pam3Cys and Pam3CSK4 (Pam3-Cys-Ser-Lys4) are synthetic triacylated lipoproteins (TLR2/1 agonists) in which Pam3Cys was shown to promote a Th2-biased response and airway inflammation [45], while Pam3CSK4 reduced Th2 cytokine release, airway hyper-reactivity (AHR), IgE levels, airway inflammation and nasal symptoms in murine models of asthma and AR [46-48]. In addition to the structural differences in the amino acid tail, these opposite effects may originate from the schedule of administration; protective effects of Pam3CSK4 have been reported when administrated after sensitization with a dose of $100 \mu \mathrm{g}$ per mouse [46, 47], while Pam3Cys was shown to be allergenic when administered in combination with ovalbumin with a dose of $50 \mu \mathrm{g}$ per mouse to induce sensitization [45]. Interestingly, in vitro co-stimulation of peripheral blood mononuclear cells (PBMCs) obtained from atopic asthmatics with Pam3CSK4 either during SIT [49] or outside of SIT [50] resulted in expanding the CD8+CD25+Foxp3+ $\mathrm{T}$-reg population, suppression of $\mathrm{CD} 4+$ proliferation and dampening of the Th2 cytokine production. These findings suggest that Pam3CSK4 may be a good adjuvant for SIT. Certain TLR2 agonists that have shown anti-asthmatic effects are described below.

\section{Macrophage-Activating Lipopeptide-2}

Macrophage-activating lipopeptide-2 or MALP-2 (evidence from mechanism based studies, level 5) is a TLR2/6 agonist obtained from Mycoplasma fermentans. MALP-2 can induce CD80 (B7-1), CD86 (B7-2), major histocompatibility complex I and II and CD40 expression in B cells 
Fig. 1. a Cell surface TLRs include TLR1, 2, 6, 10, 4 and 5. Their ligands are structures in the cell wall of invading pathogens as well as allergens like HDMs and short ragweed. Intracellular endosomal membranebound TLRs include TLR3, TLR7, TLR8 and TLR9. They recognize genetic materials of viruses and bacteria. MyD88, TIRAP and TRIF are the main adaptor molecules. Interferon regulatory factor $3 / 7$ (IRF3/7), $\mathrm{P} 50$ and $\mathrm{P} 65$, nuclear factor-kB (NF-kB) and AP1 transcription factors enhance expression of proinflammatory cytokines, chemokines and type 1 IFNs. TLR4 uses both of the MyD88-dependent and TRIFdependent pathways. Several inhibitors regulate the signaling cascade of PRRs at different steps and include: IL-1 receptorassociated kinase-M (IRAK-M), suppressor of cytokine signaling (SOCS), MAPK phosphatase-1 (MKP-1), Toll-interacting protein (TOLLIP) and TRAF family member-associated NF-kB (TANK).

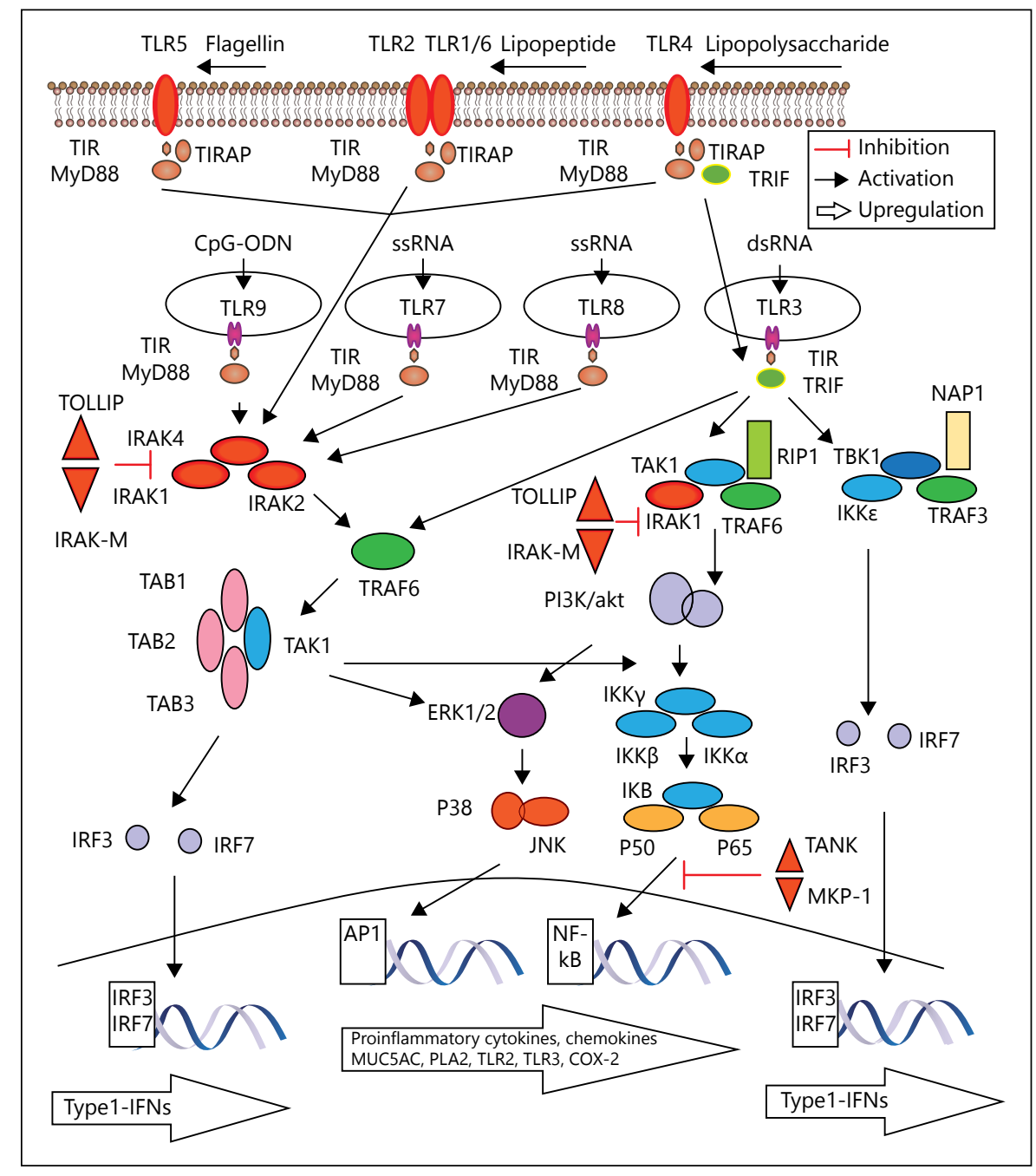

and dendritic cells (DCs) $[51,52]$. Furthermore, MALP-2 has the ability to increase the release of interferon- $\gamma$ $($ IFN- $\gamma)$ from DCs in response to allergens [53]. Mucosal delivery of MALP-2 via the intratracheal route resulted in a marked decrease in AHR, eosinophilia and Th2 cytokines in a murine model of asthma [54]. In addition, MALP-2 promoted airway neutrophilia and the production of the IL-12 p70 subunit [54]. Interestingly, it has been shown that MALP-2 is able to activate neutrophils to produce chemokines and stimulate T cell, B cell and natural killer cell accumulation in the lung of treated mice, with more potency in male and adult subjects [55]. Bisacyloxypropylcysteine polyethylene glycol (BPPcysMPEG) is a derivate of MALP-2 that is also capable of stimulating TLR2/ 6 and also has the ability to abrogate Th2 response and airway eosinophilia in murine asthma models [56]. BPPcysMPEG exerts its immunomodulatory effects by in- ducing production of IL- $1 \beta$, chemokine (C-C motif) ligand 4 (CCL4; macrophage inflammatory protein-1 $\beta$ ) and IL-10 in viable precision-cut slices of lung tissues in vitro [57]. Both systemic and local delivery of BPPcysMPEG with allergens leads to the maturation of DCs and induction of appropriate adaptive immune response against the allergen in sensitized mice [58]. In mice sensitized to house dust mites (HDMs), BPPcysMPEG also reduced eosinophilia and Th2 cytokine production and enhanced TNF- $\alpha$ and IFN- $\gamma$ generation accompanied by the induction of a Th1 response in bronchoalveolar lavage fluid and mediastinal lymph nodes [59].

\section{Lipoprotein 1}

Lipoprotein 1 (Opr1; evidence from mechanism-based studies, level 5) is a TLR2/4 agonist obtained from Pseudomonas aeruginosa, and can prime DCs and T cells to 
produce IL-12 and IFN- $\gamma$, respectively. Additionally, its co-administration with ovalbumin abolished the production of IL-4, IL-13 and airway eosinophilia in a murine asthma model [60]. Lipopeptide-CGP40774 (LP40; evidence from mechanism-based studies, level 5) is a similar TLR2 agonist capable of shifting the immune response toward a Th1 profile, reducing IgE production, AHR and airway inflammation, and increasing the T-reg response $[25,61]$. Additionally, it has been shown that LP40 can suppress allergic airway dysfunction and accompanying airway eosinophilia in mice $[25,61]$.

\section{TLR4/MD2/CD14}

Targeting of TLR4 to modify asthma/AR is based on the activation of TLR4 as an adjuvant in allergy vaccines to induce tolerance, and the inhibition of expression and inflammatory function of TLR4 with a TLR4 antagonist. Since TLR4 is upregulated in patients with asthma/AR, its targeting via allergy vaccines seems to work efficiently; however, it should be done with caution to preserve the safety of patients.

\section{Adjuvants of Allergy Vaccines}

MPL $^{\circledR}$ (monophosphoryl lipid A), a TLR4 agonist, is a detoxified derivate from Salmonella minnesota that is used in the Pollinex Quattro allergy vaccine (Allergy Therapeutics, Worthing, UK; phase IV clinical trial for AR, phase I/II for asthma). Pollinex Quattro is a glutaraldehyde modified L-tyrosine adsorbed pollen allergen (formulations containing grass, flower and tree pollens are available) with MPL that can be administered via subcutaneous or sublingual routes. The dose of MPL administered orally can be 15 times higher than that used in subcutaneous injection therapy. This TLR4 agonist

Fig. 2. Changes to the immune profile following immunotherapy with two well-studied vaccines containing TLR 4/9 agonists. Pollinex Quattro contains MPL, a TLR4 agonist, and AIC contains 1018 ISS, a TLR9 agonist versus placebo. a Pollinex Quattro schedule is as follows: weekly injection of up-dosing vaccine with 300$2,000 \mathrm{SU}, 2-8$ weeks prior to the pollen season. It is safe and efficient in abolishing symptoms of AR/asthma-sensitized patients to pollens. It also shifts the Th2 response toward Th1/T-reg and IgE toward IgG production. Of note, IgG production is differed based on pollen since Timothy and $\mathrm{rPhl} \mathrm{p} 5$ allergen-containing vaccines induced greater values of IgG than other pollens. The allergenspecific lymphocyte proliferation response is increased with the maximum quantities prior to the last injection of Pollinex Quattro has been evaluated in children over 6 years of age with similar safety and efficacy as compared with adult patients [62]. Pre-seasonal ultra-short SIT with Pollinex Quattro can alter the course of respiratory allergy in either the upper or lower respiratory tract [63] and its beneficial effects have been shown to be sustained for over 5 years $[63,64]$. Interestingly, it prevents new sensitizations and asthma development after the cessation of treatment [64]. Along with clinical improvements, the immune profile of patients will be changed through immunotherapy with MPL serving as a strong inducer of the Th1 response [65] (fig. 2a). In post-marketing open clinical trials conducted by Rosewich et al. $[62,66]$, the symptom scores and medication requirements decreased during the 3 years following the first course of injection and were augmented with subsequent injections. In their experience, clinical improvements were associated with T-reg induction and shifting from IgE to blocking IgG production. Similarly, a pre-seasonal ultra-short course of Pollinex Quattro led to a decrease in lung inflammation in asthmatics in terms of oxidative stress markers such as 8-isoprostane in exhaled breath condensate [63]. No life-threatening side effects were reported and transient local reactions were seen only with the dose of 2,000 standard units (SU)/ml (fig. 3). No toxicity with the safety margin used in the clinic was detected in experimental studies [67]. Polymite ${ }^{\circledR}$ (evidence from mechanismbased studies, level 5) is a glutaraldehyde-modified L-tyrosine adsorbed mite (Dermatophagoides pteronyssinus and $D$. farina) protein extract with MPL. The formula of $10: 50: 20 \mathrm{mg} / \mathrm{ml}$ for protein:MPL:tyrosine is used in the Polymite vaccine. Subcutaneous injection of Polymite resulted in minimal side effects or toxicity with a lowdose injection $(0.1-1 \mathrm{ml} /$ week for 13 weeks) in rodents [68]. To the best of our knowledge no study has tested its efficacy to date.

$[64,136,139]$. b The AIC schedule is as follows: weekly injection of up-dosing AIC with 0.06-12.0 $\mu \mathrm{g}$ (Amb a 1: 1018 ISS molar ratio of 1: 4). Tulic et al. [129], Asai et al. [126] and Creticos et al. [127] started their studies before the ragweed season of 2001, and Tulic et al. [129] and Creticos et al. [127] followed their participants until the ragweed season of 2002. Only assessed immunologic variables with at least one significant change between active versus placebo have been stated ( $\mathrm{p}<0.05$; significant). Nasal symptoms included rhinorrhea, pruritus, sneezing and nasal congestion, and the chest symptoms included tightness, wheezing, cough and shortness of breath. Cytokines were measured using supernatant culture of fresh PBMCs from participants exposed with 100 $\mu \mathrm{g} / \mathrm{ml}$ ragweed [126-129].

(For figure see next page.)
Aryan/Holgate/Radzioch/Rezaei 


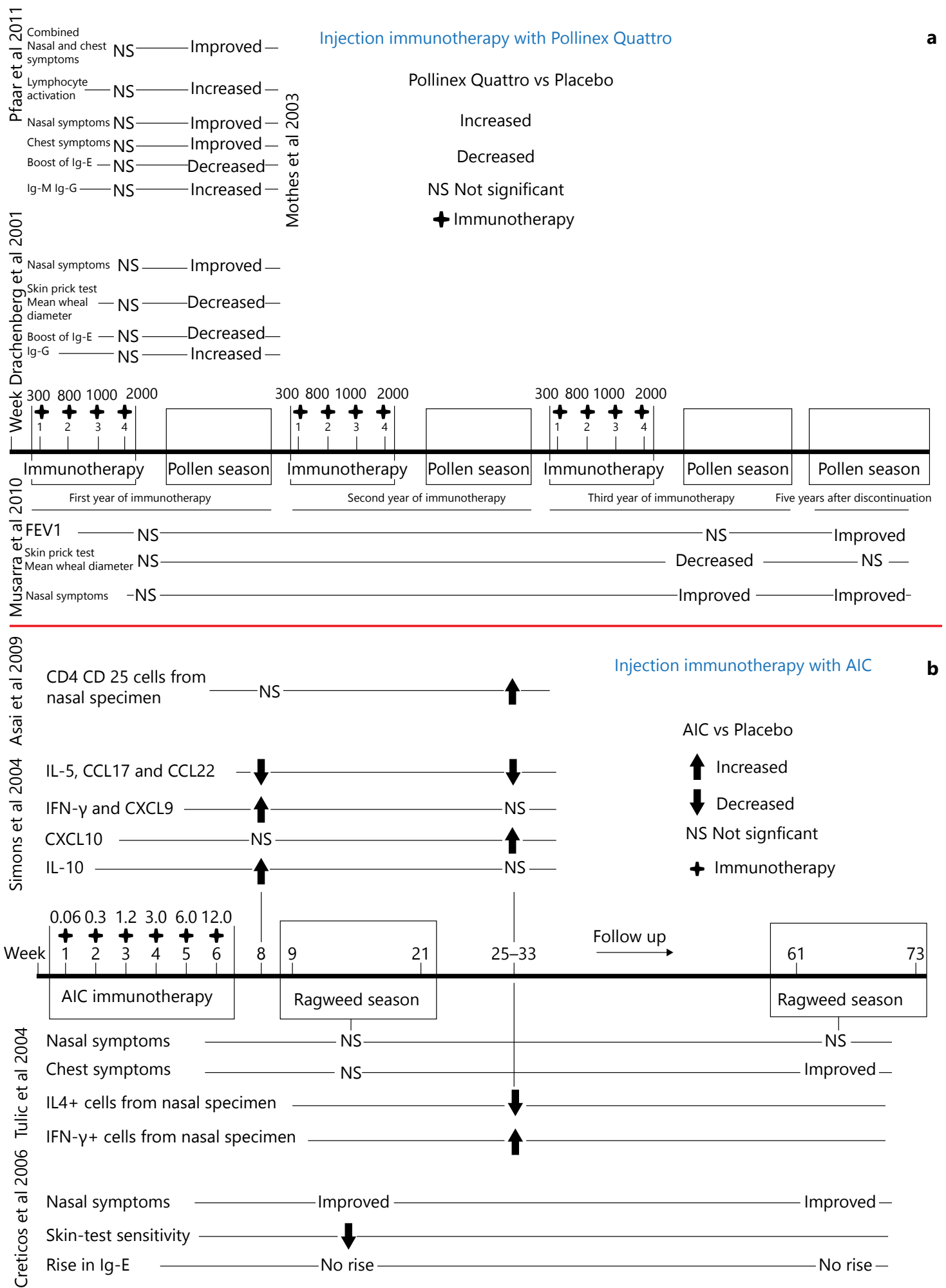



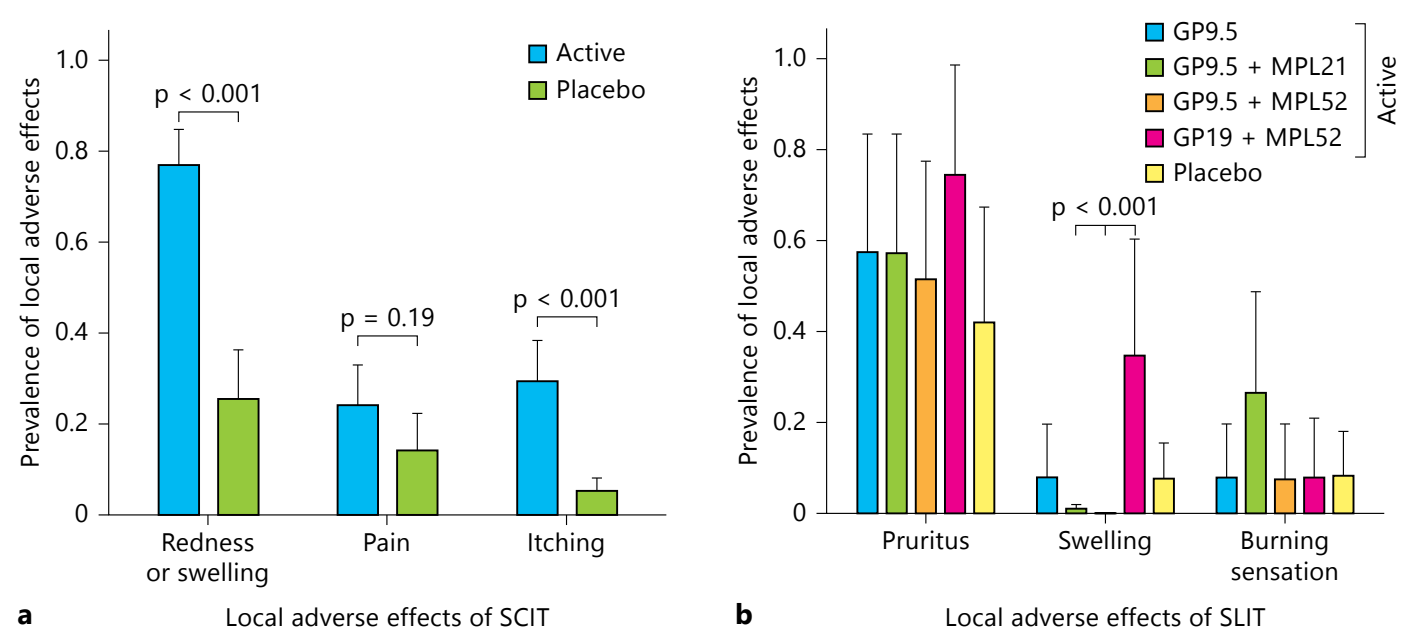

a

Local adverse effects of SCIT

$$
\text { b }
$$

Local adverse effects of SLIT
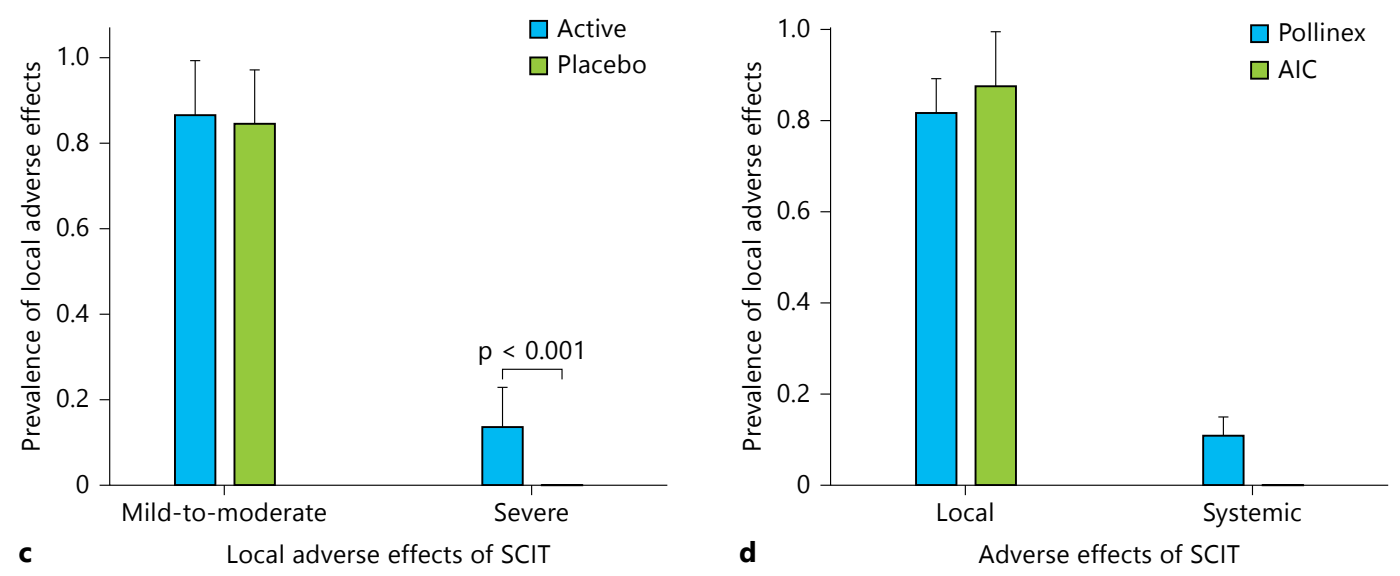

Fig. 3. Safety profile of two well-studied vaccines containing TLR4/9 agonists. The side effects of allergy vaccines of Pollinex Quattro, which contains MPL, a TLR4 agonist, and AIC, which contains 1018 ISS, a TLR9 agonist. The Pollinex Quattro with grass pollens and the same preparation with tree pollens elicited slightly higher local side effects [137]. a The most common local adverse effects of subcutaneous immunotherapy (SCIT) with Pollinex Quattro as the active group include: redness or swelling $(61 / 81,75 \%)$, pain $(19 / 81,23 \%)$ and itching $(23 / 81,28 \%)$ [139]. b The most common local adverse effects of sublingual immunotherapy (SLIT) with Pollinex Quattro as the active group include: pruritus $(26 / 48,54 \%)$, swelling $(4 / 48$, $9 \%)$ and burning sensation $(5 / 48,10 \%)$. The materials employed in active treatment included grass major allergen Phleum pratense $(\mathrm{Phl}$ p) and MPL as follows: GP9.5: $9.45 \mu \mathrm{g}$ of Phl p 1; GP9.5 + MPL21: $9.45 \mu \mathrm{g}$ of Phl p $1+21 \mu \mathrm{g}$ of MPL; GP9.5 + MPL52 $9.45 \mu \mathrm{g}$ of Phl p $1+52.5 \mu \mathrm{g}$ of MPL, and GP19 + MPL52: $19.04 \mu \mathrm{g}$ of Phl p $1+52.5$

\section{Monotherapy with TLR4 Agonist}

All data are from mechanism-based studies, level 5 of evidence except CRX675 (phase I/II clinical trial for AR, level 2), which is an aqueous MPL compound, the intranasal administration of which led to the reduction of na-

$\mu \mathrm{g}$ of MPL. Placebo was the buffered glycerine solution [136]. c The local adverse effects of SCIT immunotherapy with AIC were categorized as mild-to-moderate versus severe by Tulic et al. [129], and none of them required any medication. $\mathbf{d}$ Total local and systemic side effects of immunotherapy with Pollinex Quattro or AIC obtained from the aforementioned studies. Systemic side effects included rhinoconjuctivitis, joint pain, headaches, nausea, hot flushes, chills, hypotension and tachycardia. The probability of a systemic reaction by injection of Pollinex Quattro was 8.6\%, while it was $10.7 \%$ with AIC. No anaphylactic shock was reported due to either Pollinex Quattro or AIC administration. Error bars have been used to present the prevalence of adverse effects. Comparisons were made using $\chi^{2}$ test with SPSS version 16.0 (SPSS Inc., Chicago, Ill., USA). Probabilities of less than 0.05 were considered significant and shown as $\mathrm{p}$ for corresponding comparisons.

sal symptoms of AR patients only at a dose of $100 \mu \mathrm{g}$ [69]. A similar compound of lipid-A exerted anti-asthmatic effects in a murine model of asthma as monotherapy. In this model, it was able to reduce total serum IgE levels, AHR, airway eosinophilia and IL-13 production [48]. 
Poly- $\gamma$-glutamic acid ( $\gamma$-PGA) is a TLR4 agonist obtained from the cell wall of bacilli which induces expression of the co-stimulatory molecules, CD80, CD86 and CD40 on DCs, and also upregulates IL-12 [70]. Its administration to a murine model of allergic-type lung inflammation led to the suppression of the Th2 cytokines, AHR, airway inflammation and eosinophilia [70]. ER803022 is another synthetic TLR4 agonist that showed anti-asthmatic effects in murine models. It inhibited AHR, airway eosinophilia and Th2 cytokine production on TLR-dependent MyD88 activation and IL-12/IFN- $\gamma$ production, rather than a TIRAP-inducing interferon- $\beta$ (TRIF)-dependent cascade [71]. UT12, an agonistic antibody against TLR4, can suppress airway-allergic disease through the abrogating production of $\mathrm{Th} 2$ and $\mathrm{Th} 17$ cytokines without the induction of T-reg or Th1 cytokines [72]. On the other hand, E5564 is a TLR4 antagonist that was safe and efficient in reducing IL-6 generation, AHR, airway inflammation, neutrophilia and eosinophilia in allergen-sensitized and challenged mice [73].

\section{TLR5}

TLR5, another cell surface TLR, recognizes flagellin and triggers the MyD88-dependent signaling cascade. Its expression has been shown in monocyte-derived cells [30], neutrophils [74], eosinophils [74], airway epithelial cells [75] and airway smooth muscle cells (ASMCs) [76]. Some claim that its expression and function is not different between asthmatics and non-asthmatics $[30,74]$, while others believe that its expression in the airways is decreased in asthmatics [77]. Indoor allergens such as those from HDMs are thought to promote allergic respiratory disease, a Th2-biased response and IgE production in part due to inappropriate TLR5 activation [17]. On the other hand, TLR5 is also implicated in the defense against many pathogens of the respiratory system such as Pseudomonas aeruginosa [75], Yersinia pestis [78], Streptococcus pneumoniae [79] and influenza virus [80] in such a way that the addition of flagellin to the formulation of vaccines against the aforementioned pathogens enhanced the efficacy of immunization. Interestingly, when co-administered with the allergens, flagellin was shown to reduce AHR, inflammatory cell influx to airways and Th2 type cytokine production in an ovalbumin murine model of allergic airway inflammation [81] via the induction of T-reg responses [82]. Accordingly, TLR5 looks like a double- edged sword; on one hand, it can be the criminal in producing an exaggerated and inappropriate response to innocuous aeroallergens in allergic patients, while on the other hand, TLR5 ligands are strong adjuvants either in allergy vaccines or vaccines against infectious agents (evidence from mechanism-based studies, level 5).

\section{Intracellular TLRs}

Intracellular TLRs recognize the genomic material of invading pathogens and their most important role is to trigger appropriate antiviral responses. TLR3, 7, 8 and 9 are intracellular TLRs and their signaling cascade is depicted in figure $1[19,23,41,42]$. Viral infections, especially with rhinovirus, account for the most common causes of asthma exacerbation in children and cause more severe forms of wheezing episodes in allergic subjects [83]. As described below, boosting the immune response through targeting these TLRs may promise a etiologic treatment for patients with respiratory allergy in the shape of an allergy vaccine (evidence from a phase II clinical trial) or lead to more effective drugs in viral-induced asthma exacerbations, such as imidazoquinoline compounds (evidence from mechanism based studies, level 5).

\section{TLR3: Sensor of Double-Stranded RNA}

TLR3 activation mimics a viral infection that alters the immune response and airway microenvironment toward inflammation [84, 85], AHR [86] and bronchospasm [87]. TLR3 agonists such as polyinosinic-polycytidylic acid (polyI:C) at a low dose are used to create in vitro and animal models of viral-induced asthma $[86,88]$. Accordingly, the employment of TLR3 inhibitors seems to be beneficial for the treatment of respiratory allergies, and there is one report regarding the usefulness of polyI:C, a TLR3 agonist, in the suppression of murine allergic airway inflammation [89].

\section{PolyI:C}

Despite all the inflammatory effects of polyI:C (evidence from mechanism-based studies, level 5), Sel et al. [89] found that systemic administration of $200 \mu \mathrm{g} / 200 \mu \mathrm{l}$ of polyI:C reduced AHR, inflammation and IgE production in murine models of asthma via the induction of IL10 and IL-12 production. Interestingly, the dose of polyI:C 
used in this study $(200 \mu \mathrm{g} / 200 \mu \mathrm{l})$ [89] was similar to what others $(1 \mathrm{mg} / 1 \mathrm{ml})$ [86] employed to induce an asthma phenotype.

\section{Capsazepinoids}

Analogues to capsazepine (in vitro results) have been recently shown to act as a TLR3 inhibitor. They suppress the production of inflammatory cytokines including TNF- $\alpha$, IL- 8 and TSLP (thymic stromal lymphopoietin) by airway epithelial cells collected from asthmatics [90]. Additionally, they have revealed bronchodilator effects by relaxation of ASMCs. Indeed, these compounds are believed to reverse AHR induced by polyI:C [90].

\section{Single-Stranded DNA Oligonucleotides}

Single-stranded DNA oligonucleotides (ssDNAODNs; evidence from mechanism-based studies, level 5) inhibit not only binding of the polyI:C to TLR3, but also production of proinflammatory cytokines triggered by TLR3 activation in PBMCs [91]. Intranasal administration of ssDNA-ODNs prevented Th2-type lung inflammation in a non-human primate model and suppressed inflammatory cell infiltration into the respiratory tract in monkeys treated with polyI:C [91].

\section{Resveratrol}

Resveratrol or trans-3,4,5-trihydroxystilbene (evidence from mechanism-based studies, level 5) is a herbal extract that is abundant in grapes. It showed protective effects on asthma development following RSV infection by preventing upregulation of TLR3 expression and inhibition of its adaptor molecule TRIF [24].

\section{TLR7 and TLR8: Sensors of Single-Stranded Viral RNA}

Imidazoquinoline is a common structure among TLR7/8 agonists; however, other classes, such as poly(RNA) molecules, also exist [92]. The employment of lipid carriers, phosphorothioate modification of RNA backbone or addition of arabinonucleotides prevents nuclease degradation and increase the stability of the product [93]. Systemic administration of TLR7/8 agonists resulted in fatal side effects, including peripheral leukocyte depletion due to systemic activation of endothelia that express vascular adhesion molecules [94] and progressive lymphoid destruction mimicking HIV-mediated immunopathology [95], perhaps due to the TNF- $\alpha$ storm [96] induced by this particular type of TLR7 agonist. Taken together, it will be important to choose the proper TLR7/8 ligand, its dose and route of administration to develop a safe and efficient protocol for the treatment of patients with allergic asthma, which of course should be done under the close supervision of physicians.

\section{Imiquimod}

Imiquimod or R837: $\left(\right.$ Aldara $^{\circledR}, 3 \mathrm{M}$ pharmaceutics, mechanism-based studies, level 5 of evidence) is an FDA-approved drug used for treating skin basal cell carcinoma, actinic keratosis and external genital warts with many suggested off-label benefits in other disease, such as melanoma [6]. Interestingly, it has been recently demonstrated that topical administration of this TLR7 agonist mediates systemic changes and modulates the composition of the cell/cytokine milieu of the respiratory system [97]. Imiquimod treatment of mice led to a reduction in alveolar macrophages, B cells and TNF- $\alpha$ production, along with an increase in DC and natural killer accumulation in the lung tissue and IL-10 production. Similar cellular changes in blood were also observed but without an overt inflammatory response [97]. Imiquimod also showed bronchodilator effects in both murine [98] and porcine [92] models of AHR, possibly through induction of nitric oxide, prostaglandins and large-conductance calcium-activated potassium channels, but not adenosine receptors [92]. As imiquimod can also promote antiviral defense and protect against virus-induced airway dysfunction [99], it seems an interesting drug for viral-induced asthma exacerbations.

\section{Resiquimod}

Resiquimod or R848 or S28463 (3M Pharmaceutics, Maplewood, Minn., USA; mechanism-based studies, level 5 of evidence) is a TLR7/8 agonist, the systemic $[25,89$, $100,101]$ or intranasal [96] application of which has been shown to suppress AHR and airway remodeling in murine models of asthma with similar dose responses [96, 100-103]. Resiquimod administration suppressed acute asthma with a shifting of the immune response toward Th1 and type-1 IFN production, a reduction in both Th1 and Th2 cytokine levels in the lungs of rats and mice, and a reduction in lung eosinophilia, goblet cell hyperplasia and total IgE levels [96, 100-103]. Despite consistency regarding suppression the of Th2 response, some studies report that it can suppress Th1 responses in vivo in allergic asthma in mice and rats [101]. Interestingly, resiquimod treatment resulted in the promotion of long-lasting 
protection from experimental asthma by IFN $-\gamma$ production and induction of memory CD8+ T cells [96]. Similar to imiquimod, resiquimod with concomitant antiviral and anti-asthmatic effects can be used for viral-induced asthma exacerbations [104].

\section{SA2 and PolyUs}

9-Benzyl-2-Butoxy-8-Hydroxy Adenine, also called SA2, has been shown to reduce Th17/Th2 family cytokines, neutrophilia and AHR, along with enhanced IL-10 production in murine models of allergic-type lung inflammation [105]. Distinct from this, PolyUs (21-mer single-stranded phosphorothioate polyuridylic acid), a synthetic ssRNA, has been reported to exert bronchodilator effects in a porcine model of asthma through a TLR7-dependent mechanism with induction of nitric oxide production [92] (mechanism-based studies, level 5 of evidence).

\section{AZD8848}

AZD8848 (phase II clinical trial for AR) is a TLR7 agonist that was shown to be safe and efficacious in reducing nasal symptoms in seasonal AR patients. AZD8848 led to an increase in IL-1 Ra production and a decrease in mast cell tryptase and $\alpha 2$-macroglobulin in the nasal lavage of AR patients, suggestive of a reduction in plasma exudation and mast cell activity [106]. The side effects were dose dependent and included influenza-like symptoms, epistaxis, pharyngeal pain, pyrexia, rhinorrhea, nasal blockage or ulcers, nasopharyngitis, malaise and myalgia [106].

\section{GSK2245035}

GSK2245035 (phase II clinical trial for respiratory allergy) is a highly selective TLR7 agonist suggested to be beneficial in respiratory allergy via intranasal administration. Phase I of the pharmacodynamics, safety and efficacy assessment has been completed, but so far no result has been published (NCT01480271; March 2012). Participants are now being recruited for phase II (NCT01607372; June 2012).

\section{VTX-1463}

VTX-1463 or VTX-378 (phase II clinical trial for AR) is a TLR8 agonist currently in clinical development for AR patients; its safety and efficacy has been tested with promising results. It led to a reduction in nasal symptoms in grass pollen-sensitized AR patients after a course of 5-dose intranasal treatment without any reported side effects. However, detailed results have not yet been pub- lished - only one trial has been published as an abstract [107], along with a comprehensive review by Horak [108].

\section{TLR9: Sensor of Bacterial DNA}

A decade of experimental employment of TLR9 agonists in animal models of asthma was promising [109, 110]. Synthetic TLR9 agonists reduced airway eosinophilia, IL-4, IL-5 and IgE production, and enhanced IL-10 levels in bronchoalveolar lavage fluid of murine models of asthma $[102,109,111]$. Furthermore, they inhibited airway remodeling by reducing airway collagen deposition, metalloproteinase activity and angiogenesis [112-115]. CpG-ODNs enhance the ability of the immune system to combat invading pathogens via increased expression of structures that are necessary for efficient antigen presentation [116]. They showed efficacy in reducing respiratory allergy in the context of sensitization to either pollen or fungal allergens [117] via either the subcutaneous [118] or mucosal [119] routes of administration. TLR9 ligands act as both prophylactic [109] and therapeutic [120] agents in new-onset or established [121] asthma/AR $[122,123]$ with long-lasting effects. Furthermore, CpG-ODN treatment was shown to be efficacious in this regard in both the aged murine models of AHR and the neonates [119] of a maternal transmitted model of asthma. However, mice with pre-existing severe allergic airway inflammation did not benefit from CpG-ODN administration as neither the Th2 immune response nor AHR were reduced following treatment [124]. Similarly, children with severe asthma showed a reduced response to TLR9 agonists as compared with mild asthmatics or healthy controls in terms of IL-12 or IFN production [125].

\section{Allergen-TLR9-L ISS Conjugate}

Therapeutic administration of allergen-TLR9-L ISS conjugate (AIC; Dynavax, phase II clinical trial) in sensitized mice to ragweed led to inhibition of airway inflammation [115]. Results with AIC also look promising in the clinic (fig. 2b) [126-129]. AIC administration resulted in a reduction of Th2 responses and an increase in Th1 and T-reg cytokines [128]. Along with an increased Th1/Th2 ratio, AIC led to an antibody switching from IgE dominant to neutralizing IgG production [129]. It is of note that after AIC treatment a transient increase in IgE production is possible [127]. Despite the promising results with AIC in the clinic, AIC failed to reduce nasal symptoms of AR patients in initial clinical trials [129] and there 
Table 1. TLR agonists/antagonists which may be beneficial for AHR

\begin{tabular}{|c|c|c|c|c|c|}
\hline TLR2 complexes & BPPcysMPEG $[56,58,59]$ & level 5 & $\downarrow$ & yes & no \\
\hline TLR2 complexes and TL4 & Lipoprotein 1 (Opr1) [60] & level 5 & $\downarrow$ & yes & no \\
\hline TLR4 & CRX675 [140] & level 2 & $\downarrow$ & yes & yes \\
\hline TLR4 & $\gamma$-PGA [70] & level 5 & $\downarrow$ & yes & no \\
\hline TLR4 & ER803022 [71] & level 5 & $\downarrow$ & yes & no \\
\hline TLR4 & UT12 [72] & level 5 & $\downarrow$ & no & no \\
\hline TLR4 & E5564 [73] & level 5 & $\downarrow$ & no & no \\
\hline TLR3 & ssDNA-ODN [91] & level 5 & no & no & no \\
\hline TLR7 & PolyUs [92] & level 5 & $\downarrow$ & no & yes \\
\hline TLR7 & AZD8848 [106] & level 2 & $\downarrow$ & no & no \\
\hline TLR8 & VTX-1463 [108] & level 2 & $\downarrow$ & no & no \\
\hline TLR9 & 1018ISS [126-129] & level 2 & $\downarrow$ & yes & yes \\
\hline TLR9 & QbG10 [132] & level 2 & $\downarrow$ & yes & yes \\
\hline
\end{tabular}

The highest level of evidence for efficacy of each compound for AHR is presented.

remains controversy regarding the onset and duration of its efficacy $[127,129]$. Furthermore, it failed to reduce asthma symptoms in treated children [130]. No significant local or systemic side effects related to AIC have so far been reported (fig. 3) [126-129]. Finally, administration of 1018 ISS revealed no significant improvement in the symptoms of asthmatics as a stand-alone therapy [131].

\section{QbG10}

QbG10, an A-type CpG-ODN (phase II clinical trial), has been tested in HDM-sensitized AR patients as either monotherapy [132] or in an allergy vaccine formulation [133]. It manifests the ability to reduce symptoms, concomitant medication needs and increase the quality of life of AR patients [132]. Assessment of QbG10 in mildto-moderate and moderate-to-severe asthma is now subject to ongoing clinical trials (NCT00890734 and NCT01673672, respectively). The side effects reported to be due to QbG10 administration include erythema, lymphadenopathy, influenza-like symptoms, pyrexia, fatigue and headache [132]. Recently, several new TLR9 agonists have been introduced for the treatment of patients with AR/asthma, including AZD1419 (Dynavax),
AEV0675 (Coley Pharmaceutics), SAR21609 (Coley Pharmaceutics), and IMO2134 (Idera Pharmaceutics) [134]. However, to our knowledge there is no publication regarding their efficacy or safety in AHR patients.

\section{Conclusions and Future Directions}

Since almost all the TLRs are positioned to play a sentinel role in the development of respiratory allergy, they provide major therapeutic targets to modulate the natural course of allergic disease. So far, agonists rather than antagonists of TLRs have been widely employed in therapeutic or prophylactic preparations useful for asthma/AR patients. MPL (a TLR4 agonist) and 1018 ISS (a TLR9 agonist) show strong immunogenicity effects that make them appropriate adjuvants for allergy vaccines (fig. 2). Although patients should be informed regarding possible side effects, it seems from experience to date that these are mostly local and transient (fig. 3). TLR4 and TLR9 agonists in the shape of allergy vaccines are the most promising compounds in this family to be used in the clinic. Intranasal administration of AZD8848 (TLR7 agonist) and VTX-1463 (TLR8 agonist) have revealed efficacy in the 
Table 2. Clinical efficacy of targeting TLRs

\begin{tabular}{|c|c|c|c|c|c|c|c|c|c|c|}
\hline Targeting & Study & Design & $\begin{array}{l}\text { Level of } \\
\text { evidence }\end{array}$ & Compound & $\begin{array}{l}\text { Dose of } \\
\text { compound }\end{array}$ & Route & $\begin{array}{l}\text { Participants } \\
\text { (active:placebo) }\end{array}$ & $\begin{array}{l}\text { Age, } \\
\text { years }\end{array}$ & $\begin{array}{l}\text { Symptom } \\
\text { score (active } \\
\text { vs. placebo) }\end{array}$ & $\begin{array}{l}\text { Medication } \\
\text { score (active } \\
\text { vs. placebo) }\end{array}$ \\
\hline $\begin{array}{l}\text { TLR4 } \\
\text { agonist }\end{array}$ & $\begin{array}{l}\text { DuBuske et } \\
\text { al. [135] } \\
2011\end{array}$ & $\begin{array}{l}\text { Single-center } \\
\text { RCTDB }\end{array}$ & Level 2 & $\begin{array}{l}\text { Pollinex } \\
\text { Quattro }\end{array}$ & $\begin{array}{l}300-2,000 \mathrm{SU} / \\
\mathrm{ml} \times 4 \\
\text { ultra-short } \\
\text { course }\end{array}$ & SCIT & $\begin{array}{l}\text { AR patients } \\
\text { sensitized to } \\
\text { grass pollens, } \\
514: 514\end{array}$ & NA & $\begin{array}{l}\text { Significantly } \\
\text { reduced }\end{array}$ & $\begin{array}{l}\text { Significantly } \\
\text { reduced }\end{array}$ \\
\hline $\begin{array}{l}\text { TLR4 } \\
\text { agonist }\end{array}$ & $\begin{array}{l}\text { Pfaar et al. } \\
{[136]} \\
2011\end{array}$ & $\begin{array}{l}\text { Single-center } \\
\text { RCTDB }\end{array}$ & Level 2 & $\begin{array}{l}\text { Pollinex } \\
\text { Quattro } \\
\text { rPhl p + } \\
\text { MPL }\end{array}$ & $\begin{array}{l}9.45 \text { or } 19.04 \mu \mathrm{g} \\
\text { Phl p }+21 \text { or } \\
52.5 \mu \mathrm{g} \mathrm{MPL} / \\
\text { day for } 8 \text { weeks }\end{array}$ & SLIT & $\begin{array}{l}\text { AR patients } \\
\text { sensitized to } \\
\text { grass pollen, } \\
64: 16\end{array}$ & $\begin{array}{l}35.9 \\
(18-64)\end{array}$ & $\begin{array}{l}\text { NA } \\
\text { (combined } \\
\text { symptom and } \\
\text { medication } \\
\text { score was } \\
\text { reduced) }\end{array}$ & $\begin{array}{l}\text { NA } \\
\text { (combined } \\
\text { symptom and } \\
\text { medication } \\
\text { score was } \\
\text { reduced) }\end{array}$ \\
\hline $\begin{array}{l}\text { TLR4 } \\
\text { agonist }\end{array}$ & $\begin{array}{l}\text { Musarra } \\
\text { et al. [64] } \\
2010\end{array}$ & $\begin{array}{l}\text { Single-center } \\
\text { open clinical } \\
\text { trial }\end{array}$ & Level 2 & $\begin{array}{l}\text { Pollinex } \\
\text { Quattro }\end{array}$ & $\begin{array}{l}300-2,000 \mathrm{SU} / \\
\mathrm{ml} \times 4 \\
\text { ultra-short } \\
\text { course }\end{array}$ & SCIT & $\begin{array}{l}\text { AR/asthma- } \\
\text { sensitized } \\
\text { patients to grass } \\
\text { pollen, 29:28 }\end{array}$ & $\begin{array}{l}33.7 \\
(10-59)\end{array}$ & $\begin{array}{l}\text { Significantly } \\
\text { reduced as } \\
\text { assessed by } \\
\text { VAS }\end{array}$ & NA \\
\hline $\begin{array}{l}\text { TLR4 } \\
\text { agonist }\end{array}$ & $\begin{array}{l}\text { Rosewich et } \\
\text { al. [66] } 2010\end{array}$ & $\begin{array}{l}\text { Post-marketing } \\
\text { multi-center } \\
\text { open trial } \\
\text { (cohort) }\end{array}$ & Level 3 & $\begin{array}{l}\text { Pollinex } \\
\text { Quattro }\end{array}$ & $\begin{array}{l}300-2,000 \mathrm{SU} / \\
\mathrm{ml} \times 4 \\
\text { ultra-short } \\
\text { course }\end{array}$ & SCIT & $\begin{array}{l}\text { AR/asthma } \\
\text { patients } \\
\text { sensitized to } \\
\text { grass pollen, } \\
34 \text { active }\end{array}$ & $\begin{array}{l}10.2 \\
(6-18)\end{array}$ & $\begin{array}{l}\text { Significantly } \\
\text { reduced }\end{array}$ & $\begin{array}{l}\text { Significantly } \\
\text { reduced }\end{array}$ \\
\hline $\begin{array}{l}\text { TLR4 } \\
\text { agonist }\end{array}$ & $\begin{array}{l}\text { Rosewich et } \\
\text { al. [62] } 2010\end{array}$ & $\begin{array}{l}\text { Post-marketing } \\
\text { multi-center } \\
\text { open trial } \\
\text { (cohort) }\end{array}$ & Level 3 & $\begin{array}{l}\text { Pollinex } \\
\text { Quattro }\end{array}$ & $\begin{array}{l}300-2,000 \mathrm{SU} / \\
\mathrm{ml} \times 4 \\
\text { ultra-short } \\
\text { course }\end{array}$ & SCIT & $\begin{array}{l}\text { AR/asthma } \\
\text { patients } \\
\text { sensitized to } \\
\text { grass pollen, } \\
421 \text { active }\end{array}$ & $\begin{array}{l}13.2 \\
(6-18)\end{array}$ & $\begin{array}{l}\text { Significantly } \\
\text { reduced }\end{array}$ & $\begin{array}{l}\text { Significantly } \\
\text { reduced }\end{array}$ \\
\hline $\begin{array}{l}\text { TLR4 } \\
\text { agonist }\end{array}$ & $\begin{array}{l}\text { Casale et al. } \\
\text { [69] } 2006\end{array}$ & $\begin{array}{l}\text { Single-center } \\
\text { RCTDB }\end{array}$ & Level 2 & CRX-675 & $\begin{array}{l}2-20-100-200 \\
\mu g / \text { patient }\end{array}$ & Intranasal & $\begin{array}{l}\text { AR patients } \\
\text { sensitized to } \\
\text { ragweed, } 48: 16\end{array}$ & $\begin{array}{l}31.5 \\
(19-50)\end{array}$ & $\begin{array}{l}\text { Improved } \\
\text { only with } 100 \\
\mu \mathrm{g} / \text { safety } \\
\text { assessment }\end{array}$ & NA \\
\hline $\begin{array}{l}\text { TLR4 } \\
\text { agonist }\end{array}$ & $\begin{array}{l}\text { Von Baehr } \\
\text { et al. [65] } \\
2005\end{array}$ & $\begin{array}{l}\text { Single-center } \\
\text { RCT }\end{array}$ & Level 2 & $\begin{array}{l}\text { Pollinex } \\
\text { Quattro }\end{array}$ & $\begin{array}{l}300-2,000 \mathrm{SU} / \\
\mathrm{ml} \times 4 \\
\text { ultra-short } \\
\text { course }\end{array}$ & SCIT & $\begin{array}{l}\text { AR/asthma } \\
\text { patients } \\
\text { sensitized to } \\
\text { grass/tree } \\
\text { pollens, 21:14 }\end{array}$ & $\begin{array}{l}31.4 \\
(18-61)\end{array}$ & NA & NA \\
\hline $\begin{array}{l}\text { TLR4 } \\
\text { agonist }\end{array}$ & $\begin{array}{l}\text { Drachenberg } \\
\text { et al. [137] } \\
2003\end{array}$ & $\begin{array}{l}\text { Multi-center } \\
\text { open trial }\end{array}$ & Level 2 & $\begin{array}{l}\text { Pollinex } \\
\text { Quattro }\end{array}$ & $\begin{array}{l}300-2,000 \mathrm{SU} / \\
\mathrm{ml} \times 4 \\
\text { ultra-short } \\
\text { course }\end{array}$ & SCIT & $\begin{array}{l}\text { AR/asthma } \\
\text { patients } \\
\text { sensitized to } \\
\text { grass pollen, } 90 \\
\text { (all active) }\end{array}$ & $\begin{array}{l}12.5 \\
(6-17)\end{array}$ & $\begin{array}{l}\text { Significantly } \\
\text { reduced }\end{array}$ & $\begin{array}{l}\text { Significantly } \\
\text { reduced }\end{array}$ \\
\hline $\begin{array}{l}\text { TLR4 } \\
\text { agonist }\end{array}$ & $\begin{array}{l}\text { Mothes et al. } \\
\text { [138] } 2003\end{array}$ & $\begin{array}{l}\text { Single-center } \\
\text { RCTDB }\end{array}$ & Level 2 & $\begin{array}{l}\text { Pollinex } \\
\text { Quattro }\end{array}$ & $\begin{array}{l}300-2,000 \mathrm{SU} / \\
\mathrm{ml} \times 4 \\
\text { ultra-short } \\
\text { course }\end{array}$ & SCIT & $\begin{array}{l}\text { AR patients } \\
\text { sensitized to } \\
\text { pollens, } 11: 9\end{array}$ & NA & $\begin{array}{l}\text { Significantly } \\
\text { reduced }\end{array}$ & $\begin{array}{l}\text { Significantly } \\
\text { reduced }\end{array}$ \\
\hline $\begin{array}{l}\text { TLR4 } \\
\text { agonist }\end{array}$ & $\begin{array}{l}\text { Drachenberg } \\
\text { et al. [139] } \\
2001\end{array}$ & $\begin{array}{l}\text { Multi-center } \\
\text { RCTDB }\end{array}$ & Level 2 & $\begin{array}{l}\text { Pollinex } \\
\text { Quattro }\end{array}$ & $\begin{array}{l}300-2,000 \mathrm{SU} / \\
\mathrm{ml} \times 4 \\
\text { ultra-short } \\
\text { course }\end{array}$ & SCIT & $\begin{array}{l}\text { AR/asthma } \\
\text { patients } \\
\text { sensitized to } \\
\text { grass pollen, } \\
90 \text { (active), } 81: 60\end{array}$ & $\begin{array}{l}28.2 \\
(18-60)\end{array}$ & $\begin{array}{l}\text { Significantly } \\
\text { reduced }\end{array}$ & NS \\
\hline $\begin{array}{l}\text { TLR7 } \\
\text { agonist }\end{array}$ & $\begin{array}{l}\text { Greiff et al. } \\
\text { [106] } 2012\end{array}$ & $\begin{array}{l}\text { Single-center } \\
\text { RCTDB } \\
\text { NCT00770003 }\end{array}$ & Level 2 & AZD8848 & $60 \mu \mathrm{g} /$ week $\times 5$ & Intranasal & $\begin{array}{l}\text { Grass pollen-sen- } \\
\text { sitized AR pati- } \\
\text { ents, } 34: 34\end{array}$ & $\begin{array}{l}27 \\
(18-46)\end{array}$ & $\begin{array}{l}\text { Significantly } \\
\text { reduced }\end{array}$ & $\begin{array}{l}\text { Significantly } \\
\text { reduced }\end{array}$ \\
\hline
\end{tabular}


Table 2. (continued)

\begin{tabular}{|c|c|c|c|c|c|c|c|c|c|c|}
\hline Targeting & Study & Design & $\begin{array}{l}\text { Level of } \\
\text { evidence }\end{array}$ & Compound & $\begin{array}{l}\text { Dose of } \\
\text { compound }\end{array}$ & Route & $\begin{array}{l}\text { Participants } \\
\text { (active:placebo) }\end{array}$ & $\begin{array}{l}\text { Age, } \\
\text { years }\end{array}$ & $\begin{array}{l}\text { Symptom } \\
\text { score (active } \\
\text { vs. placebo) }\end{array}$ & $\begin{array}{l}\text { Medication } \\
\text { score (active } \\
\text { vs. placebo) }\end{array}$ \\
\hline $\begin{array}{l}\text { TLR9 } \\
\text { agonist }\end{array}$ & $\begin{array}{l}\text { Senti et al. } \\
\text { [133] } 2009\end{array}$ & $\begin{array}{l}\text { Single-center } \\
\text { open-label }\end{array}$ & Level 3 & QbG10 & $300 \mu \mathrm{g} /$ week $\times 6$ & SCIT & $\begin{array}{l}\text { HDM-sensitized } \\
\text { AR patients, 20:0 }\end{array}$ & $\begin{array}{l}34.0 \\
(18-56)\end{array}$ & $\begin{array}{l}\text { Significantly } \\
\text { reduced }\end{array}$ & $\begin{array}{l}\text { Significantly } \\
\text { reduced }\end{array}$ \\
\hline $\begin{array}{l}\text { TLR9 } \\
\text { agonist }\end{array}$ & $\begin{array}{l}\text { Creticos } \\
\text { et al. [127] } \\
2006\end{array}$ & $\begin{array}{l}\text { Single-center } \\
\text { RCTDB }\end{array}$ & Level 2 & $\begin{array}{l}\text { Amb a1- } \\
1018 \text { ISS } \\
\text { (AIC) }\end{array}$ & $\begin{array}{l}0.06-12 \mu \mathrm{g} / \\
\text { week } \times 6\end{array}$ & SCIT & $\begin{array}{l}\text { Ragweed- } \\
\text { sensitized AR } \\
\text { patients, 14:11 }\end{array}$ & $\begin{array}{l}39.4 \\
(23-60)\end{array}$ & $\begin{array}{l}\text { Significantly } \\
\text { reduced }\end{array}$ & $\begin{array}{l}\text { Significantly } \\
\text { reduced }\end{array}$ \\
\hline $\begin{array}{l}\text { TLR9 } \\
\text { agonist }\end{array}$ & $\begin{array}{l}\text { Gauvreau } \\
\text { et al. [131] } \\
2006\end{array}$ & $\begin{array}{l}\text { Single-center } \\
\text { RCTDB }\end{array}$ & Level 2 & 1018 ISS & $36 \mathrm{mg} /$ week $\times 4$ & Inhalation & $\begin{array}{l}\text { Atopic } \\
\text { asthmatics, } 21: 19\end{array}$ & $\begin{array}{l}24.8 \\
(18-55)\end{array}$ & NS & NS \\
\hline $\begin{array}{l}\text { TLR9 } \\
\text { agonist }\end{array}$ & $\begin{array}{l}\text { Tulic et al. } \\
\text { [129] } 2004\end{array}$ & $\begin{array}{l}\text { Single-center } \\
\text { RCTSB }\end{array}$ & Level 2 & $\begin{array}{l}\text { Amb a1- } \\
1018 \text { ISS } \\
(\mathrm{AIC})\end{array}$ & $\begin{array}{l}0.06-12 \mu \mathrm{g} / \\
\text { week } \times 6\end{array}$ & SCIT & $\begin{array}{l}\text { Ragweed- } \\
\text { sensitized AR } \\
\text { patients, 28:29 }\end{array}$ & $\begin{array}{l}39.9 \\
(27-55)\end{array}$ & $\begin{array}{l}\text { Significantly } \\
\text { reduced } \\
\text { (second year) }\end{array}$ & $\begin{array}{l}\text { Significantly } \\
\text { reduced }\end{array}$ \\
\hline
\end{tabular}

The level of evidence provided by each study has been determined according to OCEBM 2011 Levels of Evidence with respect to study design. Any significant $(\mathrm{p}<0.05)$ improvement in allergic airway symptoms compared with baseline or placebo was considered an improvement. Mothes et al. [138] and Nayak et al. [130] did not mention the exact age of participants in the full text of their articles. The full text of the study of DuBuske et al. [135] was not available and no response was received regarding the missing data from the corresponding author. NS = Not significant (active vs. placebo), symptom and medication scores were usually recorded using diary cards; RCTDB $=$ randomized double-blind clinical trial; RCTSB = randomized single-blind clinical trial; RCT = randomized clinical trial without blindness; $\mathrm{Phl} \mathrm{p}=$ Phleum pratense $; \mathrm{NA}=$ data was not available/applicable; $\mathrm{VAS}=$ visual analogue scale. relief of symptoms in AR patients. Many other drugs that target TLRs were found to suppress airway inflammation, eosinophilia and AHR at least in animal model systems. Indeed, most of our knowledge regarding TLR agonists/ antagonists rose from experimental studies (table 1). The future for a wide variability of PRR agonists and antagonists in the manipulation of the allergic disease pathways holds considerable promise.

However, many questions remain to be answered. There is poor evidence regarding the usefulness of targeting TLRs in allergic children since most clinical trials so far have been conducted on adult participants (table 2); specifically, how much targeting of the immature immune system of a child is safe and efficacious? The answer is of utmost importance since the prevalence of atopic asthma is higher in children and in these subjects the risk of persistence of asthma into adult life is greater than in non-atopic patients. Furthermore, despite the promising experiments with ISS in dampening established AHR and airway remodeling, SIT is usually employed in mild-to-moderate asthma; therefore, it remains to be established if targeting of TLRs could be successfully applied to severe asthma. Finally, timing, dosage, patient selection and many other questions regarding the best formulation to be utilized in targeting the TLRs need to be answered since inappropriate administration may precipitate exaggerated immune responses.

\section{Acknowledgement}

This study was supported by a grant from Tehran University of Medical Sciences (No. 92-01-30-21494). 


\section{References}

1 Hollams EM, Deverell M, Serralha M, Suriyaarachchi D, Parsons F, Zhang G, de Klerk N, Holt BJ, Ladyman C, Sadowska A, Rowe J, Loh R, Sly PD, Holt PG: Elucidation of asthma phenotypes in atopic teenagers through parallel immunophenotypic and clinical profiling. J Allergy Clin Immunol 2009;124:463-470.e416.

$\checkmark 2$ Bousquet J, Schunemann HJ, Samolinski B, et al: Allergic Rhinitis and Its Impact on Asthma (ARIA): achievements in 10 years and future needs. J Allergy Clin Immunol 2012;130: 1049-1062.

-3 Holt PG, Upham JW, Sly PD: Contemporaneous maturation of immunologic and respiratory functions during early childhood: implications for development of asthma prevention strategies. J Allergy Clin Immunol 2005; 116:16-25.

4 Ramaprakash H, Hogaboam CM: Intranasal CpG therapy attenuated experimental fungal asthma in a TLR9-dependent and independent manner. Int Arch Allergy Immunol 2010;152:98-112.

5 Song DJ, Min MG, Miller M, Cho JY, Yum HY, Broide DH: Toll-like receptor-9 agonist inhibits airway inflammation, remodeling and hyperreactivity in mice exposed to chronic environmental tobacco smoke and allergen. Int Arch Allergy Immunol 2010;151:285-296.

6 Hedayat M, Takeda K, Rezaei N: Prophylactic and therapeutic implications of toll-like receptor ligands. Med Res Rev 2012;32:294-325.

7 Holt PG, Sly PD: Interaction between adaptive and innate immune pathways in the pathogenesis of atopic asthma: operation of a lung/bone marrow axis. Chest 2011;139:1165-1171.

8 Homma T, Matsukura S, Hirose T, Ohnishi T, Kimura T, Kurokawa M, Ieki K, Odaka M, Suzuki S, Watanabe S, Sato M, Kawaguchi M, Schleimer RP, Adachi M: Cooperative activation of CCL 5 expression by TLR 3 and tumor necrosis factor- $\alpha$ or interferon- $\gamma$ through nuclear factor- $\kappa$ B or STAT-1 in airway epithelial cells. Int Arch Allergy Immunol 2010; 152(suppl 1):9-17.

-9 Kasakura K, Takahashi K, Aizawa T, Hosono A, Kaminogawa S: A TLR2 ligand suppresses allergic inflammatory reactions by acting directly on mast cells. Int Arch Allergy Immunol 2009; 150:359-369.

10 Kucuksezer UC, Palomares O, Ruckert B, Jartti T, Puhakka T, Nandy A, Gemicioglu B, Fahrner HB, Jung A, Deniz G, Akdis CA, Akdis M: Triggering of specific toll-like receptors and proinflammatory cytokines breaks allergen-specific $\mathrm{T}$ cell tolerance in human tonsils and peripheral blood. J Allergy Clin Immunol 2013;131:875-885.

$\checkmark 11$ Hammad H, Chieppa M, Perros F, Willart MA, Germain RN, Lambrecht BN: House dust mite allergen induces asthma via toll-like receptor 4 triggering of airway structural cells. Nat Med 2009;15:410-416.

12 Li DQ, Zhang L, Pflugfelder SC, De Paiva CS, Zhang X, Zhao G, Zheng X, Su Z, Qu Y: Short ragweed pollen triggers allergic inflammation through Toll-like receptor 4-dependent thymic stromal lymphopoietin/OX40 ligand/ OX40 signaling pathways. J Allergy Clin Immunol 2011;128:1318-1325.e2.

13 Romagnani S: Coming back to a missing immune deviation as the main explanatory mechanism for the hygiene hypothesis. $\mathrm{J} \mathrm{Al}$ lergy Clin Immunol 2007;119:1511-1513.

14 Loss G, Bitter S, Wohlgensinger J, Frei R, Roduit C, Genuneit J, Pekkanen J, Roponen M, Hirvonen MR, Dalphin JC, Dalphin ML, Riedler J, von Mutius E, Weber J, Kabesch M, Michel S, Braun-Fahrlander C, Lauener R: Prenatal and early-life exposures alter expression of innate immunity genes: the PASTURE cohort study. J Allergy Clin Immunol 2012; 130:523-530.e529.

15 Sly PD, Boner AL, Bjorksten B, Bush A, Custovic A, Eigenmann PA, Gern JE, Gerritsen J, Hamelmann E, Helms PJ, Lemanske RF, Martinez F, Pedersen S, Renz H, Sampson H, von Mutius E, Wahn U, Holt PG: Early identification of atopy in the prediction of persistent asthma in children. Lancet 2008;372:11001106.

16 Wada K, Kobayashi T, Matsuwaki Y, Moriyama $\mathrm{H}$, Kita $\mathrm{H}$ : Alternaria inhibits doublestranded RNA-induced cytokine production through Toll-like receptor 3. Int Arch Allergy Immunol 2013;161(suppl 2):75-83.

17 Wilson RH, Maruoka S, Whitehead GS, Foley JF, Flake GP, Sever ML, Zeldin DC, Kraft M, Garantziotis S, Nakano H, Cook DN: The tolllike receptor 5 ligand flagellin promotes asthma by priming allergic responses to indoor allergens. Nat Med 2012;18:1705-1710.

18 Page K, Ledford JR, Zhou P, Wills-Karp M: A TLR2 agonist in German cockroach frass activates MMP-9 release and is protective against allergic inflammation in mice. J Immunol 2009;183:3400-3408.

19 Yang H, Kong X, Wei J, Liu C, Song W, Zhang W, Wei W, He S: Cockroach allergen Per a 7 down-regulates expression of Toll-like receptor 9 and IL-12 release from P815 cells through PI3k and MAPK signaling pathways. Cell Physiol Biochem 2012;29:561-570.

20 Bauer RN, Diaz-Sanchez D, Jaspers I: Effects of air pollutants on innate immunity: the role of toll-like receptors and nucleotide-binding oligomerization domain-like receptors. J Allergy Clin Immunol 2012;129:14-26.

21 Kim TB, Kim SY, Moon KA, Park CS, Jang MK, Yun ES, Cho YS, Moon HB, Lee KY: Five-aminoimidazole-4-carboxamide- $1-\beta$ 4-ribofuranoside attenuates poly (i:C)-induced airway inflammation in a murine model of asthma. Clin Exp Allergy 2007;37: 1709-1719.

22 Mushaben EM, Brandt EB, Hershey GK, Le Cras TD: Differential effects of rapamycin and dexamethasone in mouse models of established allergic asthma. PLoS One 2013; 8:e54426.
23 Yang J, Li Q, Zhou XD, Kolosov VP, Perelman JM: Naringenin attenuates mucous hypersecretion by modulating reactive oxygen species production and inhibiting NF- $\mathrm{\kappa B}$ activity via EGFR-PI3K-Akt/ERK MAPKinase signaling in human airway epithelial cells. Mol Cell Biochem 2011;351:29-40.

24 Zang N, Xie X, Deng Y, Wu S, Wang L, Peng C, Li S, Ni K, Luo Y, Liu E: Resveratrol-mediated gamma interferon reduction prevents airway inflammation and airway hyperresponsiveness in respiratory syncytial virusinfected immunocompromised mice. J Virol 2011;85:13061-13068.

-25 Aumeunier A, Grela F, Ramadan A, Pham Van L, Bardel E, Gomez Alcala A, Jeannin P, Akira S, Bach JF, Thieblemont N: Systemic Toll-like receptor stimulation suppresses experimental allergic asthma and autoimmune diabetes in NOD mice. PLoS One 2010;5: e11484.

26 Ly NP, Litonjua A, Gold DR, Celedon JC: Gut microbiota, probiotics, and vitamin $\mathrm{D}$ : interrelated exposures influencing allergy, asthma, and obesity? J Allergy Clin Immunol 2011; 127:1087-1096.

27 Toki S, Kagaya S, Shinohara M, Wakiguchi H, Matsumoto T, Takahata Y, Morimatsu F, Saito H, Matsumoto K: Lactobacillus rhamnosus GG and Lactobacillus casei suppress Escherichia coli-induced chemokine expression in intestinal epithelial cells. Int Arch Allergy Immunol 2009;148:45-58.

28 Olivier A, Sainz-Perez A, Dong H, Sparwasser T, Majlessi L, Leclerc C: The adjuvant effect of TLR agonists on $\mathrm{CD}_{4}^{+}$effector T cells is under the indirect control of regulatory T cells. Eur J Immunol 2011;41:2303-2313.

29 Ekman AK, Virtala R, Fransson M, Adner M, Benson M, Jansson L, Cardell LO: Systemic up-regulation of TLR4 causes lipopolysaccharide-induced augmentation of nasal cytokine release in allergic rhinitis. Int Arch Allergy Immunol 2012;159:6-14.

30 Lee WI, Yao TC, Yeh KW, Chen LC, Ou LS, Huang JL: Stronger Toll-like receptor $1 / 2,4$, and $7 / 8$ but less 9 responses in peripheral blood mononuclear cells in non-infectious exacerbated asthmatic children. Immunobiology 2013;218:192-200.

-31 Tversky JR, Le TV, Bieneman AP, Chichester KL, Hamilton RG, Schroeder JT: Human blood dendritic cells from allergic subjects have impaired capacity to produce interferon- $\alpha$ via Toll-like receptor 9. Clin Exp Allergy 2008;38:781-788

32 Mansson A, Cardell LO: Role of atopic status in Toll-like receptor (TLR)7- and TLR9-mediated activation of human eosinophils. J Leukoc Biol 2009;85:719-727.

33 von Bubnoff D, Sell U, Arriens S, Specht S, Hoerauf A, Bieber T: Differential expression of Toll-like receptor 2 on dendritic cells from asymptomatic and symptomatic atopic donors. Int Arch Allergy Immunol 2012;159:41-50. 
34 Yeganeh M, Henneke P, Rezaei N, Ehl S, Thiel D, Matamoros N, Pietrogrande C, Espanol T, Litzman J, Franco JL, Sanal O, Kilic SS, Breborowicz A, Plebani A, Renner E, Rothenfusser S, Hawn TR, Woellner C, Grimbacher B: Tolllike receptor stimulation induces higher TNF- $\alpha$ secretion in peripheral blood mononuclear cells from patients with hyper IgE syndrome. Int Arch Allergy Immunol 2008; 146 190-194.

- 35 Tversky JR, Bieneman AP, Chichester KL, Hamilton RG, Schroeder JT: Subcutaneous allergen immunotherapy restores human dendritic cell innate immune function. Clin Exp Allergy 2010;40:94-102.

-36 Hiraguchi Y, Tanida H, Hosoki K, Nagao M, Tokuda R, Fujisawa T: Inhibition of eosinophil activation mediated by a Toll-like receptor 7 ligand with a combination of procaterol and budesonide. Int Arch Allergy Immunol 2011;155(suppl 1):85-89.

- 37 Vandenbulcke L, Bachert C, Van Cauwenberge $\mathrm{P}$, Claeys $\mathrm{S}$ : The innate immune system and its role in allergic disorders. Int Arch Allergy Immunol 2006;139:159-165.

- 38 Groskreutz DJ, Monick MM, Powers LS, Yarovinsky TO, Look DC, Hunninghake GW: Respiratory syncytial virus induces TLR3 protein and protein kinase $R$, leading to increased double-stranded RNA responsiveness in airway epithelial cells. J Immunol 2006; 176:1733-1740.

-39 Xie XH, Law HK, Wang LJ, Li X, Yang XQ, 52 Liu EM: Lipopolysaccharide induces IL-6 production in respiratory syncytial virus-infected airway epithelial cells through the Tolllike receptor 4 signaling pathway. Pediatr Res 2009;65:156-162.

40 Valkov E, Stamp A, Dimaio F, Baker D, Verstak B, Roversi P, Kellie S, Sweet MJ, Mansell A, Gay NJ, Martin JL, Kobe B: Crystal structure of Toll-like receptor adaptor MAL/TIRAP reveals the molecular basis for signal transduction and disease protection. Proc Natl Acad Sci USA 2011;108:14879-14884.

$\checkmark 41$ Lee IT, Lee CW, Tung WH, Wang SW, Lin CC, Shu JC, Yang CM: Cooperation of TLR2 with MyD88, PI3K, and Rac1 in lipoteichoic acid-induced cPLA2/COX-2-dependent airway inflammatory responses. Am J Pathol 2010;176:1671-1684.

42 Wong CK, Cheung PF, Ip WK, Lam CW: Intracellular signaling mechanisms regulating Toll-like receptor-mediated activation of eosinophils. Am J Respir Cell Mol Biol 2007;37: 85-96.

43 Chiou YL, Lin CY: Der p2 activates airway smooth muscle cells in a TLR2/MyD88-dependent manner to induce an inflammatory response. J Cell Physiol 2009;220:311-318.

44 Melkamu T, Squillace D, Kita H, O’Grady SM: Regulation of TLR2 expression and function in human airway epithelial cells. J Membr Biol 2009;229:101-113.

-45 Redecke V, Hacker H, Datta SK, Fermin A, Pitha PM, Broide DH, Raz E: Cutting edge: activation of Toll-like receptor 2 induces a Th2 immune response and promotes experimental asthma. J Immunol 2004;172:2739-2743.

46 Patel M, Xu D, Kewin P, Choo-Kang B, McSharry C, Thomson NC, Liew FY: TLR2 agonist ameliorates established allergic airway inflammation by promoting Th1 response and not via regulatory T cells. J Immunol 2005; 174:7558-7563.

47 Zhou C, Kang XD, Chen Z: A synthetic Tolllike receptor 2 ligand decreases allergic immune responses in a mouse rhinitis model sensitized to mite allergen. J Zhejiang Univ Sci B 2008;9:279-285.

48 Velasco G, Campo M, Manrique OJ, Bellou A, He H, Arestides RS, Schaub B, Perkins DL, Finn PW: Toll-like receptor 4 or 2 agonists decrease allergic inflammation. Am J Respir Cell Mol Biol 2005;32:218-224

-49 Tsai YG, Yang KD, Niu DM, Chien JW, Lin CY: TLR2 agonists enhance CD8 ${ }^{+}$Foxp $3^{+}$regulatory $\mathrm{T}$ cells and suppress Th2 immune responses during allergen immunotherapy. J Immunol 2010;184:7229-7237.

50 Taylor RC, Richmond P, Upham JW: Tolllike receptor 2 ligands inhibit Th2 responses to mite allergen. J Allergy Clin Immunol 2006; 117:1148-1154.

51 Weigt $\mathrm{H}$, Muhlradt PF, Emmendorffer A, Krug N, Braun A: Synthetic mycoplasma-derived lipopeptide MALP-2 induces maturation and function of dendritic cells. Immunobiology 2003;207:223-233.

52 Borsutzky S, Kretschmer K, Becker PD, Muhlradt PF, Kirschning CJ, Weiss S, Guzman CA: The mucosal adjuvant macrophage-activating lipopeptide-2 directly stimulates B lymphocytes via the TLR2 without the need of accessory cells. J Immunol 2005; 174:6308-6313.

53 Weigt H, Muhlradt PF, Larbig M, Krug N, Braun A: The Toll-like receptor-2/6 agonist macrophage-activating lipopeptide- 2 cooperates with IFN- $\gamma$ to reverse the Th2 skew in an in vitro allergy model. J Immunol 2004;172: 6080-6086.

54 Weigt H, Nassenstein C, Tschernig T, Muhlradt PF, Krug N, Braun A: Efficacy of macrophage-activating lipopeptide- 2 combined with interferon- $\gamma$ in a murine asthma model. Am J Respir Crit Care Med 2005;172:566572.

55 Pabst R, Durak D, Roos A, Luhrmann A, Tschernig T: TLR2/6 stimulation of the rat lung: effects on lymphocyte subsets, natural killer cells and dendritic cells in different parts of the air-conducting compartments and at different ages. Immunology 2009;126:132139.

56 Fuchs B, Knothe S, Rochlitzer S, Nassimi M, Greweling M, Lauenstein HD, Nassenstein C, Muller M, Ebensen T, Dittrich AM, Krug N, Guzman CA, Braun A: A toll-like receptor $2 / 6$ agonist reduces allergic airway inflammation in chronic respiratory sensitisation to timothy grass pollen antigens. Int Arch Allergy Immunol 2010;152:131-139.

57 Switalla S, Lauenstein L, Prenzler F, Knothe S, Forster C, Fieguth HG, Pfennig O, Schaumann
F, Martin C, Guzman CA, Ebensen T, Muller M, Hohlfeld JM, Krug N, Braun A, Sewald K: Natural innate cytokine response to immunomodulators and adjuvants in human precision-cut lung slices. Toxicol Appl Pharmacol 2010;246:107-115.

58 Prajeeth CK, Jirmo AC, Krishnaswamy JK, Ebensen T, Guzman CA, Weiss S, Constabel H, Schmidt RE, Behrens GM: The synthetic TLR2 agonist BPPcysMPEG leads to efficient cross-priming against co-administered and linked antigens. Eur J Immunol 2010;40: 1272-1283.

59 Knothe S, Mutschler V, Rochlitzer S, Winkler C, Ebensen T, Guzman CA, Hohlfeld J, Braun A, Muller M: Local treatment with BPPcysMPEG reduces allergic airway inflammation in sensitized mice. Immunobiology 2011;216:110-117.

60 Revets H, Pynaert G, Grooten J, De Baetselier P: Lipoprotein I, a TLR2/4 ligand modulates Th2-driven allergic immune responses. J Immunol 2005;174:1097-1103.

61 Akdis CA, Kussebi F, Pulendran B, Akdis M, Lauener RP, Schmidt-Weber CB, Klunker S, Isitmangil G, Hansjee N, Wynn TA, Dillon S, Erb P, Baschang G, Blaser K, Alkan SS: Inhibition of $\mathrm{T}$ helper 2-type responses, IgE production and eosinophilia by synthetic lipopeptides. Eur J Immunol 2003;33:27172726.

62 Rosewich M, Schulze J, Fischer von Weikersthal-Drachenberg KJ, Zielen S: Ultra-short course immunotherapy in children and adolescents during a 3-yrs post-marketing surveillance study. Pediatr Allergy Immunol 2010;21:e185-e189.

63 Scichilone N, Minaldi C, Santagata R, Battaglia S, Camarda G, Bellia V: Anti-inflammatory effects of pre-seasonal Th1-adjuvant vaccine to parietaria judaica in asthmatics. J Asthma Allergy 2011;4:19-25.

64 Musarra A, Bignardi D, Troise C, Passalacqua G: Long-lasting effect of a monophosphoryl lipid-adjuvanted immunotherapy to parietaria: a controlled field study. Eur Ann Allergy Clin Immunol 2010;42:115-119.

65 von Baehr V, Hermes A, von Baehr R, Scherf HP, Volk HD, Fischer von WeikersthalDrachenberg KJ, Woroniecki S: Allergoidspecific T-cell reaction as a measure of the immunological response to specific immunotherapy (SIT) with a Th1-adjuvanted allergy vaccine. J Investig Allergol Clin Immunol 2005;15:234-241.

66 Rosewich M, Schulze J, Eickmeier O, Telles T, Rose MA, Schubert R, Zielen S: Tolerance induction after specific immunotherapy with pollen allergoids adjuvanted by monophosphoryl lipid a in children. Clin Exp Immunol 2010;160:403-410.

67 Baldrick P, Richardson D, Woroniecki SR Lees B: Pollinex Quattro Ragweed: safety evaluation of a new allergy vaccine adjuvanted with monophosphoryl lipid A (MPL) for the treatment of ragweed pollen allergy. J Appl Toxicol 2007;27:399-409. 
68 Baldrick P, Richardson D, Wheeler AW: Safety evaluation of a glutaraldehyde modified tyrosine adsorbed housedust mite extract containing monophosphoryl lipid A (MPL) adjuvant: a new allergy vaccine for dust mite allergy. Vaccine 2001;20:737-743.

-69 Casale TB, Kessler J, Romero FA: Safety of the intranasal Toll-like receptor 4 agonist CRX675 in allergic rhinitis. Ann Allergy Asthma Immunol 2006;97:454-456.

-70 Lee K, Kim SH, Yoon HJ, Paik DJ, Kim JM, Youn J: Bacillus-derived poly- $\gamma$-glutamic acid attenuates allergic airway inflammation through a Toll-like receptor-4-dependent pathway in a murine model of asthma. Clin Exp Allergy 2011;41:1143-1156.

-71 Bortolatto J, Borducchi E, Rodriguez D, Keller AC, Faquim-Mauro E, Bortoluci KR, Mucida D, Gomes E, Christ A, Schnyder-Candrian S, Schnyder B, Ryffel B, Russo M: Toll-like receptor 4 agonists adsorbed to aluminium hydroxide adjuvant attenuate ovalbumin-specific allergic airway disease: role of MyD88 adaptor molecule and interleukin-12/interferon- $\gamma$ axis. Clin Exp Allergy 2008;38:1668-1679.

-72 Matsushita H, Ohta S, Shiraishi H, Suzuki S, Arima K, Toda S, Tanaka H, Nagai H, Kimoto M, Inokuchi A, Izuhara K: Endotoxin tolerance attenuates airway allergic inflammation in model mice by suppression of the T-cell stimulatory effect of dendritic cells. Int Immunol 2010;22:739-747.

-73 Savov JD, Brass DM, Lawson BL, McElvaniaTekippe E, Walker JK, Schwartz DA: Toll-like receptor 4 antagonist (E5564) prevents the chronic airway response to inhaled lipopolysaccharide. Am J Physiol Lung Cell Mol Physiol 2005;289:L329-L337.

-74 Peake HL, Prosser AC, Thompson PJ: Expression of Toll-like receptors on neutrophils and eosinophils isolated from individuals with and without asthma. J Allergy Clin Immunol 2006;117:S14.

75 Raoust E, Balloy V, Garcia-Verdugo I, Touqui L, Ramphal R, Chignard M: Pseudomonas aeruginosa LPS or flagellin are sufficient to activate TLR-dependent signaling in murine alveolar macrophages and airway epithelial cells. PLoS One 2009;4:e7259.

-76 Sukkar MB, Xie S, Khorasani NM, Kon OM, Stanbridge R, Issa R, Chung KF: Toll-like receptor 2, 3, and 4 expression and function in human airway smooth muscle. J Allergy Clin Immunol 2006;118:641-648.

77 Lun SW, Wong CK, Ko FW, Hui DS, Lam $\mathrm{CW}$ : Expression and functional analysis of Toll-like receptors of peripheral blood cells in asthmatic patients: implication for immunopathological mechanism in asthma. J Clin Immunol 2009;29:330-342.

-78 Honko AN, Sriranganathan N, Lees CJ, Mizel SB: Flagellin is an effective adjuvant for immunization against lethal respiratory challenge with Yersinia pestis. Infect Immun 2006; 74:1113-1120.

-79 Nguyen CT, Kim SY, Kim MS, Lee SE, Rhee $\mathrm{JH}$ : Intranasal immunization with recombi- nant PspA fused with a flagellin enhances cross-protective immunity against Streptococcus pneumoniae infection in mice. Vaccine 2011;29:5731-5739.

80 Hong SH, Byun YH, Nguyen CT, Kim SY, Seong BL, Park S, Woo GJ, Yoon Y, Koh JT, Fujihashi K, Rhee JH, Lee SE: Intranasal administration of a flagellin-adjuvanted inactivated influenza vaccine enhances mucosal immune responses to protect mice against lethal infection. Vaccine 2012;30:466-474.

81 Lee SE, Koh YI, Kim MK, Kim YR, Kim SY, Nam JH, Choi YD, Bae SJ, Ko YJ, Ryu HJ, Koh JT, Choy HE, Rhee JH: Inhibition of airway allergic disease by co-administration of flagellin with allergen. J Clin Immunol 2008;28: 157-165.

82 Schülke S, Waibler Z, Mende M-S, Zoccatelli G, Vieths S, Toda M, Scheurer S: Fusion protein of TLR5-ligand and allergen potentiates activation and IL-10 secretion in murine myeloid DC. Mol Immunol 2010;48:341-350.

-83 Bacharier LB, Phillips BR, Bloomberg GR, Zeiger RS, Paul IM, Krawiec M, Guilbert T, Chinchilli VM, Strunk RC: Severe intermittent wheezing in preschool children: a distinct phenotype. J Allergy Clin Immunol 2007;119: 604-610.

84 Shiraishi Y, Asano K, Niimi K, Fukunaga K, Wakaki M, Kagyo J, Takihara T, Ueda S, Nakajima T, Oguma T, Suzuki Y, Shiomi T, Sayama K, Kagawa S, Ikeda E, Hirai H, Nagata K, Nakamura M, Miyasho T, Ishizaka A: Cyclooxygenase-2/prostaglandin D2/CRTH2 pathway mediates double-stranded RNA-induced enhancement of allergic airway inflammation. J Immunol 2008;180:541-549.

-85 Uller L, Leino M, Bedke N, Sammut D, Green B, Lau L, Howarth PH, Holgate ST, Davies DE: Double-stranded RNA induces disproportionate expression of thymic stromal lymphopoietin versus interferon- $\beta$ in bronchial epithelial cells from donors with asthma. Thorax 2010;65:626-632.

86 Starkhammar M, Kumlien Georen S, Swedin L, Dahlen SE, Adner M, Cardell LO: Intranasal administration of poly(I:C) and LPS in $\mathrm{BALB} / \mathrm{c}$ mice induces airway hyperresponsiveness and inflammation via different pathways. PLoS One 2012;7:e32110.

87 Morishima H, Kajiwara K, Akiyama K, Yanagihara Y: Ligation of Toll-like receptor 3 differentially regulates $\mathrm{M} 2$ and $\mathrm{M} 3$ muscarinic receptor expression and function in human airway smooth muscle cells. Int Arch Allergy Immunol 2008;145:163-174.

88 Choi JP, Kim YS, Kim OY, Kim YM, Jeon SG, Roh TY, Park JS, Gho YS, Kim YK: TNF- $\alpha$ is a key mediator in the development of Th2 cell response to inhaled allergens induced by a viral PAMP double-stranded RNA. Allergy 2012;67:1138-1148.

89 Sel S, Wegmann M, Bauer S, Garn H, Alber G, Renz H: Immunomodulatory effects of viral TLR ligands on experimental asthma depend on the additive effects of IL-12 and IL-10. J Immunol 2007; 178:7805-7813.
\$0 Mahmutovic-Persson I, Johansson M, Brandelius A, Calven J, Bjermer L, Yudina Y, Uller L: Capacity of capsazepinoids to relax human small airways and inhibit TLR3-induced TSLP and IFN $\beta$ production in diseased bronchial epithelial cells. Int Immunopharmacol 2012;13:292-300.

-91 Skold AE, Hasan M, Vargas L, Saidi H, Bosquet N, Le Grand R, Smith CI, Spetz AL: Single-stranded DNA oligonucleotides inhibit TLR3-mediated responses in human monocyte-derived dendritic cells and in vivo in cynomolgus macaques. Blood 2012;120:768777.

92 Kaufman EH, Fryer AD, Jacoby DB: Tolllike receptor 7 agonists are potent and rapid bronchodilators in guinea pigs. J Allergy Clin Immunol 2011;127:462-469.

$\$ 93$ Lan T, Bhagat L, Wang D, Dai M, Kandimalla ER, Agrawal S: Synthetic oligoribonucleotides containing arabinonucleotides act as agonists of TLR7 and 8. Bioorg Med Chem Lett 2009;19:2044-2047.

-94 Gunzer M, Riemann H, Basoglu Y, Hillmer A, Weishaupt C, Balkow S, Benninghoff B, Ernst B, Steinert M, Scholzen T, Sunderkotter C, Grabbe S: Systemic administration of a TLR7 ligand leads to transient immune incompetence due to peripheral-blood leukocyte depletion. Blood 2005; 106:24242432.

95 Baenziger S, Heikenwalder M, Johansen P, Schlaepfer E, Hofer U, Miller RC, Diemand S, Honda K, Kundig TM, Aguzzi A, Speck RF: Triggering TLR7 in mice induces immune activation and lymphoid system disruption, resembling HIV-mediated pathology. Blood 2009;113:377-388.

96 Xirakia C, Koltsida O, Stavropoulos A, Thanassopoulou A, Aidinis V, Sideras P, Andreakos E: Toll-like receptor 7-triggered immune response in the lung mediates acute and long-lasting suppression of experimental asthma. Am J Respir Crit Care Med 2010; 181:1207-1216.

-97 Hackstein H, Hagel N, Knoche A, Kranz S, Lohmeyer J, von Wulffen W, Kershaw O, Gruber AD, Bein G, Baal N: Skin TLR7 triggering promotes accumulation of respiratory dendritic cells and natural killer cells. PLoS One 2012;7:e43320.

98 Ekman AK, Adner M, Cardell LO: Toll-like receptor 7 activation reduces the contractile response of airway smooth muscle. Eur J Pharmacol 2011;652:145-151.

-99 Stokes JR, Sorkness RL, Kaplan MR, Castleman WL, Tomai MA, Miller RL, Lemanske RF Jr: Attenuation of virus-induced airway dysfunction in rats treated with imiquimod. Eur Respir J 1998;11:324-329.

100 Camateros P, Tamaoka M, Hassan M, Marino R, Moisan J, Marion D, Guiot MC, Martin JG, Radzioch D: Chronic asthmainduced airway remodeling is prevented by Toll-like receptor-7/8 ligand s28463. Am J Respir Crit Care Med 2007;175: 1241-1249. 
101 Moisan J, Camateros P, Thuraisingam T, Marion D, Koohsari H, Martin P, Boghdady ML, Ding A, Gaestel M, Guiot MC, Martin JG, Radzioch D: TLR7 ligand prevents allergen-induced airway hyperresponsiveness and eosinophilia in allergic asthma by a MYD88-dependent and MK2-independent pathway. Am J Physiol Lung Cell Mol Physiol 2006;290:L987-L995.

102 Duechs MJ, Hahn C, Benediktus E, WernerKlein M, Braun A, Hoymann HG, Gantner F, Erb KJ: TLR agonist mediated suppression of allergic responses is associated with increased innate inflammation in the airways. Pulm Pharmacol Ther 2011;24:203214.

103 Quarcoo D, Weixler S, Joachim RA, Stock P, Kallinich T, Ahrens B, Hamelmann E: Resiquimod, a new immune response modifier from the family of imidazoquinolinamines, inhibits allergen-induced Th2 responses, airway inflammation and airway hyper-reactivity in mice. Clin Exp Allergy 2004;34: 1314-1320.

104 Grela F, Aumeunier A, Bardel E, Van LP, Bourgeois E, Vanoirbeek J, Leite-de-Moraes M, Schneider E, Dy M, Herbelin A, Thieblemont N: The TLR7 agonist R848 alleviates allergic inflammation by targeting invariant NKT cells to produce IFN- $\gamma$. J Immunol 2011;186:284-290.

105 Vultaggio A, Nencini F, Pratesi S, Maggi L, Guarna A, Annunziato F, Romagnani S, Parronchi P, Maggi E: The TLR7 ligand 9-benzyl-2-butoxy-8-hydroxy adenine inhibits IL-17 response by eliciting IL-10 and IL10-inducing cytokines. J Immunol 2011;186: 4707-4715.

106 Greiff L, Cervin A, Ahlstrom-Emanuelsson C, Almqvist G, Andersson M, Dolata J, Eriksson L, Hogestatt E, Kallen A, Norlen P, Sjolin IL, Widegren H: Repeated intranasal TLR7 stimulation reduces allergen responsiveness in allergic rhinitis. Respir Res 2012; 13:53.

-107 Horak F, Zieglmayer P, Zieglmayer R, Lemell P, Newkirk M, Manjarrez K, Randall TD, Hershberg R: Intranasal Tolllike receptor 8 agonist (vtx-1463) significantly improves symptoms of allergic rhinitis in a randomized, placebo-controlled trial. J Allergy Clin Immunol 2011;127: AB199.

108 Horak F: VTX-1463, a novel TLR8 agonist for the treatment of allergic rhinitis. Expert Opin Investig Drugs 2011;20:981-986.

109 Kline JN, Waldschmidt TJ, Businga TR, Lemish JE, Weinstock JV, Thorne PS, Krieg AM: Modulation of airway inflammation by CpG oligodeoxynucleotides in a murine model of asthma. J Immunol 1998;160: 2555-2559.

$\checkmark 110$ Kim HK, Lee CH, Kim JM, Ayush O, Im SY, Lee HK: Biphasic late airway hyperresponsiveness in a murine model of asthma. Int Arch Allergy Immunol 2012;160:173183.
111 Zhang BY, Chi S, Sun Y: Modulation of Toll-like signal path of allergic asthma by CpG-ODNs from Bordetella pertussis (in Chinese). Yao Xue Xue Bao 2011;46:285292.

112 Luhrmann A, Tschernig T, von der Leyen $\mathrm{H}$, Hecker M, Pabst R, Wagner AH: Decoy oligodeoxynucleotide against STAT transcription factors decreases allergic inflammation in a rat asthma model. Exp Lung Res 2010; 36:85-93.

113 Jain VV, Kitagaki K, Businga T, Hussain I, George C, O’Shaughnessy P, Kline JN: CpGoligodeoxynucleotides inhibit airway remodeling in a murine model of chronic asthma. J Allergy Clin Immunol 2002;110:867872.

114 Lee SY, Cho JY, Miller M, McElwain K, McElwain S, Sriramarao P, Raz E, Broide DH: Immunostimulatory DNA inhibits allergen-induced peribronchial angiogenesis in mice. J Allergy Clin Immunol 2006;117: 597-603.

115 Santeliz JV, Van Nest G, Traquina P, Larsen E, Wills-Karp M: Amb a 1-linked CpG oligodeoxynucleotides reverse established airway hyperresponsiveness in a murine model of asthma. J Allergy Clin Immunol 2002;109: 455-462.

116 Chiang DJ, Ye YL, Chen WL, Lee YL, Hsu NY, Chiang BL: Ribavirin or CpG DNA sequence-modulated dendritic cells decrease the IgE level and airway inflammation. Am J Respir Crit Care Med 2003;168: 575-580.

-117 Banerjee B, Kelly KJ, Fink JN, Henderson JD Jr, Bansal NK, Kurup VP: Modulation of airway inflammation by immunostimulatory $\mathrm{CpG}$ oligodeoxynucleotides in a murine model of allergic aspergillosis. Infect Immun 2004;72:6087-6094.

-118 Ashino S, Wakita D, Zhang Y, Chamoto K, Kitamura H, Nishimura T: CpG-ODN inhibits airway inflammation at effector phase through down-regulation of antigen-specific Th2-cell migration into lung. Int Immunol 2008;20:259-266.

119 Fedulov A, Silverman E, Xiang Y, Leme A, Kobzik L: Immunostimulatory CpG oligonucleotides abrogate allergic susceptibility in a murine model of maternal asthma transmission. J Immunol 2005; 175:42924300.

120 Serebrisky D, Teper AA, Huang CK, Lee SY, Zhang TF, Schofield BH, Kattan M, Sampson HA, Li XM: CpG oligodeoxynucleotides can reverse Th2-associated allergic airway responses and alter the B7.1/B7.2 expression in a murine model of asthma. J Immunol 2000;165:5906-5912.

-121 Kline JN, Kitagaki K, Businga TR, Jain VV: Treatment of established asthma in a murine model using $\mathrm{CpG}$ oligodeoxynucleotides. Am J Physiol Lung Cell Mol Physiol 2002; 283:L170-L179.

-122 Hussain I, Jain VV, Kitagaki K, Businga TR, O'Shaughnessy P, Kline JN: Modulation of murine allergic rhinosinusitis by $\mathrm{CpG}$ oligodeoxynucleotides. Laryngoscope 2002;112: 1819-1826.

123 Rhee CS, Libet L, Chisholm D, Takabayashi K, Baird S, Bigby TD, Lee CH, Horner AA, Raz E: Allergen-independent immunostimulatory sequence oligodeoxynucleotide therapy attenuates experimental allergic rhinitis. Immunology 2004;113:106-113.

124 Trujillo-Vargas CM, Ramirez-Pineda JR, Palmetshofer A, Grunewald S, Moll H, Berberich C, Erb KJ: Mice vaccinated with allergen-pulsed myeloid dendritic cells are not protected from developing allergen-induced Th2 responses. Int Arch Allergy Immunol 2005;137:219-228.

125 Kapoor S, Geng L, Feldman A, Jyonouchi H: Characterization of severe asthma (SA) in children of inner-city of Newark: altered responses to recall antigens and a panel of agonists of Toll-like receptors (TLR). J Allergy Clin Immunol 2011;127:AB61.

126 Asai K, Foley SC, Sumi Y, Yamauchi Y, Takeda N, Desrosiers M, Lavigne F, Hamid Q: Amb a 1-immunostimulatory oligodeoxynucleotide conjugate immunotherapy increases $\mathrm{CD} 4{ }^{+} \mathrm{CD} 25^{+} \mathrm{T}$ cells in the nasal mucosa of subjects with allergic rhinitis. Allergol Int 2008;57:377-381.

127 Creticos PS, Schroeder JT, Hamilton RG, Balcer-Whaley SL, Khattignavong AP, Lindblad R, Li H, Coffman R, Seyfert V, Eiden JJ, Broide D: Immunotherapy with a ragweedToll-like receptor 9 agonist vaccine for allergic rhinitis. N Engl J Med 2006;355:14451455.

128 Simons FE, Shikishima Y, Van Nest G, Eiden JJ, HayGlass KT: Selective immune redirection in humans with ragweed allergy by injecting Amb a 1 linked to immunostimulatory DNA. J Allergy Clin Immunol 2004; 113:1144-1151.

129 Tulic MK, Fiset PO, Christodoulopoulos P, Vaillancourt P, Desrosiers M, Lavigne F, Eiden J, Hamid Q: Amb a 1-immunostimulatory oligodeoxynucleotide conjugate immunotherapy decreases the nasal inflammatory response. J Allergy Clin Immunol 2004;113: 235-241.

130 Nayak AS, Tripathy I, Levitt D: Novel Amb a $1 \mathrm{CpG}$ oligodeoxyribonucleotide conjugate ragweed vaccine administered to children. J Allergy Clin Immunol 2006;117: S159.

131 Gauvreau GM, Hessel EM, Boulet LP, Coffman RL, O’Byrne PM: Immunostimulatory sequences regulate interferon-inducible genes but not allergic airway responses. Am J Respir Crit Care Med 2006;174:1520.

132 Klimek L, Willers J, Hammann-Haenni A, Pfaar O, Stocker H, Mueller P, Renner WA, Bachmann MF: Assessment of clinical efficacy of CYT003-QbG10 in patients with allergic rhinoconjunctivitis: a phase $\mathrm{IIb}$ study. Clin Exp Allergy 2011;41:13051312. 
133 Senti G, Johansen P, Haug S, Bull C, Gottschaller C, Muller P, Pfister T, Maurer P, Bachmann MF, Graf N, Kundig TM: Use of a-type $\mathrm{CpG}$ oligodeoxynucleotides as an adjuvant in allergen-specific immunotherapy in humans: a phase I/IIa clinical trial. Clin Exp Allergy 2009;39:562-570.

134 Connolly DJ, O’Neill LA: New developments in Toll-like receptor targeted therapeutics. Curr Opin Pharmacol 2012;12:510518.

135 DuBuske LM, Frew AJ, Horak F, Keith PK, Corrigan CJ, Aberer W, Holdich T, von Weikersthal-Drachenberg KJ: Ultrashortspecific immunotherapy successfully treats seasonal allergic rhinoconjunctivitis to grass pollen. Allergy Asthma Proc 2011;32:239247.
136 Pfaar O, Barth C, Jaschke C, Hormann K, Klimek L: Sublingual allergen-specific immunotherapy adjuvanted with monophosphoryl lipid A: a phase I/IIa study. Int Arch Allergy Immunol 2011;154:336-344.

137 Drachenberg KJ, Heinzkill M, Urban E, Woroniecki SR: Efficacy and tolerability of short-term specific immunotherapy with pollen allergoids adjuvanted by monophosphoryl lipid a (MPL) for children and adolescents. Allergol Immunopathol (Madr) 2003;31:270-277.
38 Mothes N, Heinzkill M, Drachenberg KJ, Sperr WR, Krauth MT, Majlesi Y, Semper H, Valent P, Niederberger V, Kraft D, Valenta R: Allergen-specific immunotherapy with a monophosphoryl lipid A-adjuvanted vaccine: reduced seasonally boosted immunoglobulin $\mathrm{E}$ production and inhibition of basophil histamine release by therapy-induced blocking antibodies. Clin Exp Allergy 2003;33:1198-1208.

39 Drachenberg KJ, Wheeler AW, Stuebner P, Horak F: A well-tolerated grass pollen-specific allergy vaccine containing a novel adjuvant, monophosphoryl lipid $\mathrm{A}$, reduces allergic symptoms after only four preseasonal injections. Allergy 2001;56:498-505.

140 Immunostimulatory DNA-Dynavax: AIC, Amba 1 immunostimulatoryconjugate, $\mathrm{HBV}$ ISS, ISS 1018, ISS DNA, ISS DNA-Dynavax, ISS1, ISS2. Drugs R\&D 2002;3:193-196. 